Copyright (C) 2014 by Academic Publishing House Researcher

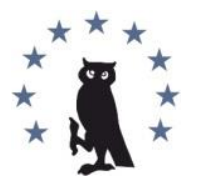

Published in the Russian Federation

European Researcher

Has been issued since 2010.

ISSN 2219-8229

E-ISSN 2224-0136

Vol. 82, No. 9-1, pp. 1564-1590, 2014

DOI: $10.13187 /$ er.2014.82.1564

www.erjournal.ru

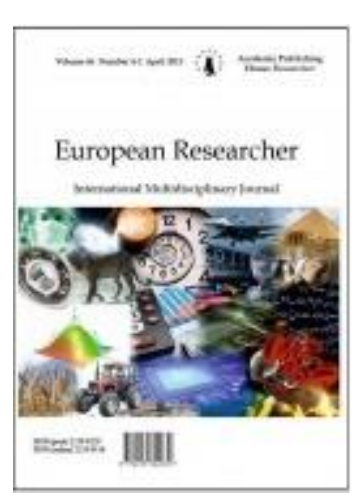

Chemical Sciences

Химические науки

UDC 541311

\title{
Zeolites Modified Metal Cations as Catalysts in Hydrocarbon Oxidation and the Alkyl Alcohol
}

\author{
${ }^{1}$ Agadadsh Makhmud Aliyev \\ ${ }_{2}^{2}$ Zumrud Abdulmutallib Shabanova \\ 3 Fikret Vakhid Aliyev \\ ${ }_{4}^{4}$ Alla M. Guseynova
}

1-4 Azerbaijan National Academy of Sciences, Institute of Catalysis and Inorganic Chemistry named after acad. M.F. Nagiyev, Azerbaijan

${ }^{1}$ Academician, Doctor of Chemistry

E-mail:iradam@rambler.ru

${ }^{2}$ Doctor of Philosophy in Chemistry, a leading researcher

E-mail: iradam@rambler.ru

3 Researcher

E-mail: iradam@rambler.ru

$4 \mathrm{PhD}$, a leading researcher

E-mail: iradam@rambler.ru

\begin{abstract}
The results of studies on the creation of highly metalltceolitnyh systems and the study of their catalytic activities in the oxidation of lower olefin hydrocarbons (ethylene to acetaldehyde, acetone, propylene, butylene methyl ethyl ketone); aliphatic $\mathrm{C}_{1}-\mathrm{C}_{5}$ alcohols to their corresponding aldehydes, ketones, carboxylic acids and carboxylic acid esters; oxidative dehydrogenation of naphthenes in the alicyclic diene hydrocarbons and the oxidative dimerization of methane to acetylene. It has been established that the selectivity of these catalysts determined optimal combination of metal components with the acidity and the structure of the zeolite. Selected highly effective catalysts for the reactions studied. Based on the results of experimental studies of the kinetics of the reactions of oxidation of lower olefin hydrocarbons and aliphatic alcohols, the oxidative dehydrogenation of naphthenes and oxidative coupling of methane on the synthesized catalysts are represented by their probable stepwise mechanism and kinetic models developed reactions.
\end{abstract}

Keywords: metalleolitnye catalysts; oxidation; hydrocarbons; aliphatic alcohols. 


\section{Введение}

Наиболее важной фундаментальной проблемой в области катализа является зависимость каталитических свойств от размеров металлических частиц. До сих пор изучалось влияние дисперсности при вариации размера частиц $\geq 10 \AA$, включающих несколько десятков и более атомов металла. Регулируемое распределение кислотных центров на поверхности, ионообменные свойства, большая внутренняя поверхность, молекулярноситовая селективность в катализе, сформированная каталитическая структура с однородными порами и термическая стабильность цеолитов создают благоприятные условия для создания на их основе, модифицированных методом ионного обмена катионами металлов с известными каталитическими свойствами, высокодисперсных каталитических систем для разных реакций. Кроме того, путем восстановления катионов, введенных методом ионного обмена на поверхность цеолита, водородом и их окисления кислородом также можно получить высокодисперсные металлические и металлоксидные цеолитные каталитические системы соответственно. Следует отметить, что некоторые реакции, например парциальное окисление алифатических спиртов протекают с участием двух активных центров: ионы металлов (восстановленные металлы, оксиды металлов) и бренстедовские кислотные центры средней силы, которые также можно реализовать на поверхности цеолита. Изучение таких сложных каталитических систем с использованием цеолитных носителей, имеет не только научное, но и прикладное значение, так как катализаторы такого типа перспективны в ряде процессов нефтепереработки и нефтехимии, в частности - в процессах гидрогенизационного облагораживания нефтяного сырья $[1,2]$.

В настоящей работе приведены результаты исследования по приготовлению высокодисперсных каталитических систем методом ионного обмена на основе синтетических и природных цеолитов и металлов с известными каталитическими свойствами для реакций: окисления низших олефиновых углеводородов в карбонильные соединения; парциального окисления алифатических спиртов; окислительного дегидрирования нафтенов и окислительной димеризации метана.

Экспериментальная часть. Образцы катализатора для реакций газофазного окисления низших олефиновых углеводородов в карбонильные соединения готовили методом ионного обмена на основе известной окислительно-восстановительной каталитической системы для жидкофазного варианта этого процесса, $\mathrm{PdCl}_{2}-\mathrm{CuCl}_{2}$ [3] и синтетического цеолита $\mathrm{NaY}$ с $\mathrm{SiO}_{2} / \mathrm{Al}_{2} \mathrm{O}_{3}=4.2$, который имеет относительно высокую концентрацию кислотных центров средней силы [4]. Ионы $\mathrm{Cu}^{2+}$ и $\left[\mathrm{Pd}\left(\mathrm{NH}_{3}\right)_{4}\right]^{2+}$ вводили методом ионного обмена из водных растворов $\mathrm{CuCl}_{2}$ и $\left[\mathrm{Pd}\left(\mathrm{NH}_{3}\right)_{4}\right] \mathrm{Cl}_{2}$ с последующей отмывкой от $\mathrm{Cl}^{-}$с сушкой при $120^{\circ} \mathrm{C}$ в течение 5 ч [5].

Катализаторы для парофазного окисления алифатических спиртов и для окислительного дегидрирования нафтенов готовили на основе синтетических и природных цеолитов и разных катионов [6-10]; для окислительного сочетания метана использованы высококремнистые цеолиты и природный клиноптилолит [11] и катионы $\mathrm{Li}^{+}, \mathrm{Ca}^{2+}, \mathrm{Mg}^{2+}$, $\mathrm{Mn}^{2+}$; и др. Количество введённых элементов в состав цеолита было определено ионоспекральным анализом на AAS 300 - Perkin Elmer и ICP-MS Agilent 7700.

Испытание активности синтезированных образцов катализаторов для реакций: окисления низших олефиновых углеводородов в карбонильные соединения; парциального окисления алифатических спиртов, окислительного превращения метана и окислительного дегидрирования нафтенов проводили на проточно-циркуляционной установке с пирексовым реактором, на проточной установке с трубчатым пирексовым реактором, на проточной установке с двухступенчатым кварцевым реактором со ступенчатой подачей кислорода и на проточной установке с кварцевым реактором $[5,9,10,12]$, соответственно. Продукты реакции анализировали методом газо-жидкостной хроматографии с использованием колонок, заполненных полисорбом; сепароном W, GNH цеолитом, NaX и паропаком-Т в условиях линейно-программированного подъема температуры. Анализ продуктов реакции проводился также на газовом хроматографе «Agilent 7890» с массовым детектором «Agilent-5975» с колонкой HР-5 MS длиной 30 м.

Формирование металлического компонента в цеолитах осуществляли в токе водорода при температурах $500-750^{\circ} \mathrm{C}$. Ниже приведены результаты исследования и обсуждения 
процессов: газофазного окисления низших олефиновых углеводородов в карбонильные соединения, парциального окисления алифатических спиртов, селективного окислительного дегидрирования нафтеновых углеводородов и окислительной димеризации метана на цеолитных катализаторах модифицированных катионами металлов методом ионного обмена.

Газофазное окисление низших олефиновых углеводородов в карбонильные соединения на цеолитных катализаторах модифицированных катионами металлов.

Для реакции газофазного окисления этилена в ацетальдегид были синтезированы цеолитные катализаторы $\mathrm{CuPdNaY}$ с различным содержанием палладия и меди. Содержание меди менялось от 0.1 до 10.0 \%, а палладия - от 0.025 до $2.5 \%$ от веса цеолита [13]. Из синтезированных образцов катализатора наиболее высокую активность проявлял CuPdNaY, содержащий $1.5 \% \mathrm{Pd}^{2+}$ и $6.0 \% \mathrm{Cu}^{2+}$. Испытание активности образцов катализатора проводили в интервале температур $105-125^{\circ} \mathrm{C}$ при атмосферном давлении при парциальных давлениях: кислорода $-(0.125 \div 0.275)$ атм., водяного пара - $(0.125 \div 0.275)$ атм. и этилена $-(0.125 \div 0.175)$ атм. и времени контакта - $(0.67 \div 2.0)$ г (кат) ·ч/л.

В табл. 1 представлены результаты экспериментального исследования кинетических закономерностей реакции газофазного окисления этилена в ацетальдегид на цеолитном катализаторе $\mathrm{CuPdNaY,} \mathrm{содержащий} 1.5$ вес. \% $\mathrm{Pd}^{2+}$ и 6.0 вес. \% $\mathrm{Cu}^{2+}$.

Таким образом, известная окислительно-восстановительная каталитическая система для жидкофазного окисления низших олефиновых углеводородов в карбонильные соединения, $\mathrm{PdCl}_{2}-\mathrm{CuCl}_{2}$, при введении его основных компонентов, $\mathrm{Pd}^{2+}$ и $\mathrm{Cu}^{2+}$ методом ионного обмена на поверхность цеолита проявляет высокую каталитическую активность в газофазном варианте этой реакции [14, 15-17]. Этим методом приготовлены также катализаторы для газофазного окисления пропилена в ацетон и бутиленов в метилэтилкетон [18-19].

Таблица 1

\section{Экспериментальные кинетические данные для газофазной реакции окисления этилена в ацетальдегид}

\begin{tabular}{|c|c|c|c|c|c|c|c|c|c|}
\hline $\mathrm{T}$ & $\mathrm{G}_{\mathrm{k}} / \mathrm{F}$ & $P_{O_{2}}^{0}$ & $P_{C_{2} H_{4}}^{0}$ & $P_{\mathrm{H}_{2} \mathrm{O}}^{0}$ & $\begin{array}{c}\text { Степень } \\
\text { превращ } \\
\text { ения, }\end{array}$ & $\begin{array}{c}\text { Выход } \\
\text { ацетальд } \\
\text { егида }\end{array}$ & $\begin{array}{c}\text { Выход } \\
\text { диоксид } \\
\text { a } \\
\text { углерод } \\
\text { a }\end{array}$ & $r_{\mathrm{CH}_{3} \mathrm{CHO}} \cdot 1 \mathrm{O}^{-4}$ & $r_{\mathrm{CO}_{2}} \cdot 1 \mathrm{O}^{-4}$ \\
\hline${ }^{\circ} \mathrm{C}$ & $\begin{array}{l}\text { г(кат) } \\
\text {.час/л }\end{array}$ & атм. & атм. & атм. & $\%$ & $\%$ & $\%$ & $\begin{array}{c}\text { моль/г(кат) } \\
\text { час } \\
\end{array}$ & $\begin{array}{c}\text { моль/г(кат) } \\
\text { час } \\
\end{array}$ \\
\hline 105 & 1.2 & $\begin{array}{c}0.20 \\
0 \\
\end{array}$ & 0.1 & 0.2 & 14.63 & 14.31 & 0.32 & 4.9656 & 0.1110 \\
\hline 105 & 1.2 & $\begin{array}{c}0.25 \\
0\end{array}$ & 0.1 & 0.2 & 14.43 & 14.00 & 0.43 & 4.8580 & 0.1492 \\
\hline 110 & 1.2 & 0.150 & 0.1 & 0.2 & 14.93 & 14.06 & 0.87 & 4.8788 & 0.3018 \\
\hline 110 & 1.2 & 0.175 & 0.1 & 0.2 & 18.81 & 17.68 & 1.13 & 6.1249 & 0.3921 \\
\hline 120 & 1.2 & 0.225 & 0.1 & 0.2 & 22.68 & 20.70 & 1.98 & 7.1829 & 0.6870 \\
\hline 125 & 1.2 & 0.275 & 0.1 & 0.2 & 21.68 & 18.67 & 3.01 & 6.4785 & 0.9098 \\
\hline 110 & 1.2 & 0.1 & 0.2 & $\begin{array}{c}0.20 \\
0\end{array}$ & 19.44 & 18.13 & 1.31 & 6.2950 & 0.4549 \\
\hline 120 & 1.2 & 0.1 & 0.2 & 0.150 & 21.69 & 17.88 & 3.81 & 6.2082 & 1.3229 \\
\hline 120 & 1.2 & 0.1 & 0.2 & $\begin{array}{c}0.22 \\
5\end{array}$ & 23.64 & 21.48 & 2.16 & $7 \cdot 4582$ & 0.7499 \\
\hline 125 & 1.2 & 0.1 & 0.2 & 0.125 & 19.99 & 14.42 & 5.57 & 5.0068 & 1.9340 \\
\hline 125 & 1.2 & 0.1 & 0.2 & $\begin{array}{c}0.20 \\
0\end{array}$ & 21.85 & 19.03 & 2.82 & 6.6125 & 0.9799 \\
\hline 110 & 1.2 & 0.2 & 0.050 & 0.2 & 30.06 & 28.76 & 1.30 & 4.9929 & 0.2257 \\
\hline 110 & 1.2 & 0.2 & 0.100 & 0.2 & 19.44 & 18.13 & 1.31 & 6.2950 & 0.4548 \\
\hline 120 & 1.2 & 0.2 & 0.050 & 0.2 & 33.25 & 31.23 & 2.02 & 5.4217 & 0.3507 \\
\hline
\end{tabular}




\begin{tabular}{|c|c|c|c|c|c|c|c|c|c|}
\hline 125 & 1.2 & 0.2 & 0.025 & 0.2 & 38.26 & 36.64 & 1.62 & 3.1803 & 0.1406 \\
\hline 125 & 1.2 & 0.2 & 0.100 & 0.2 & 21.85 & 19.03 & 2.82 & 6.6075 & 0.9791 \\
\hline 120 & 0.67 & 0.2 & 0.1 & 0.2 & 11.39 & 10.50 & 0.89 & 6.5625 & 0.5562 \\
\hline 120 & 0.8 & 0.2 & 0.1 & 0.2 & 13.14 & 12.06 & 1.08 & 6.7969 & 0.6099 \\
\hline 120 & 1.0 & 0.2 & 0.1 & 0.2 & 18.94 & 17.25 & 1.69 & 7.1875 & 0.7042 \\
\hline 120 & 1.2 & 0.2 & 0.1 & 0.2 & 23.11 & 20.87 & 2.24 & 7.2464 & 0.7778 \\
\hline 120 & 2.0 & 0.2 & 0.1 & 0.2 & 23.37 & 19.80 & 3.57 & 4.12500 & 0.743750 \\
\hline
\end{tabular}

Анализ литературных материалов позволил заключить, что механизм окисления этилена в ацетальдегид в газовой фазе на гетерогенизированных катализаторах сходен с механизмом, который установлен для жидкофазного варианта осуществления реакции в присутствии каталитического раствора хлористой меди и хлористого палладия [20]. Поэтому можно предположить, что газофазное окисление этилена протекает с участием тех же промежуточных комплексов, которые предложены и доказаны физическими методами для жидкофазного варианта осуществления этой реакции. На основании известной аналогии и проведенных нами экспериментальных исследований предложен стадийный механизм газофазной реакции окисления этилена в ацетальдегид на катализаторе $\mathrm{CuPdNaY} \mathrm{c} \mathrm{учетом}$ образования побочного продукта - двуокиси углерода и реокисления палладия.

$\mathrm{Pd}^{2+} Z_{2}+\mathrm{H}_{2} \mathrm{O} \underset{K_{l}}{\longleftrightarrow} \mathrm{Pd}^{2+}\left(\mathrm{H}_{2} \mathrm{O}\right) Z_{2}^{-}$

$\mathrm{Pd}^{2+}\left(\mathrm{H}_{2} \mathrm{O}\right) Z_{2}^{-}+\mathrm{C}_{2} \mathrm{H}_{4} \underset{K_{2}}{\longleftrightarrow} \mathrm{Pd}^{2+}\left(\mathrm{H}_{2} \mathrm{O}\right)\left(\mathrm{C}_{2} \mathrm{H}_{4}\right) Z_{2}^{-}$

$\mathrm{Pd}^{2+}\left(\mathrm{H}_{2} \mathrm{O}\right)\left(\mathrm{C}_{2} \mathrm{H}_{4}\right) Z_{2}^{-}+\mathrm{H}_{2} \mathrm{O} \underset{K_{3}}{\rightleftarrows} \mathrm{Pd}^{2+}\left(\mathrm{C}_{2} \mathrm{H}_{4}\right)\left(\mathrm{OH}^{-}\right) Z^{-}+\mathrm{H}_{3} \mathrm{O}^{+} Z^{-} \quad$ III

$\mathrm{Pd}^{2+}\left(\mathrm{C}_{2} \mathrm{H}_{4}\right)\left(\mathrm{OH}^{-}\right) Z^{-}+\mathrm{H}_{3} \mathrm{O}^{+} Z^{-}+\mathrm{H}_{2} \mathrm{O} \underset{K_{4}}{\longleftrightarrow} \mathrm{OHCH}_{2} \mathrm{CH}_{2} \mathrm{Pd}^{2+}\left(\mathrm{H}_{2} \mathrm{O}\right) Z^{-} \quad$ IV

$\mathrm{OHCH}_{2} \mathrm{CH}_{2} \mathrm{Pd}^{2+}\left(\mathrm{H}_{2} \mathrm{O}\right) Z \stackrel{k}{\longrightarrow} \mathrm{CH}_{3} \mathrm{CHO}+\mathrm{Pd}^{\mathrm{o}}+\mathrm{H}_{3} \mathrm{O}^{+} Z \quad$ V

$\mathrm{OHCH}_{2} \mathrm{CH}_{2} \mathrm{Pd}^{2+}\left(\mathrm{H}_{2} \mathrm{O}\right) Z^{-}+5^{-} \mathrm{Cu}^{2+} \mathrm{O}^{-} \stackrel{k_{\mathrm{n}}}{\longrightarrow} 2 \mathrm{CO}_{2}+2 \mathrm{H}_{2} \mathrm{O}+\mathrm{Pd}^{\mathrm{o}}+\mathrm{H}_{3} \mathrm{O}^{+} Z^{-}+5 \mathrm{Cu}^{+} Z^{-} \quad$ VI

$\mathrm{Pd}^{\mathrm{o}}+2 \mathrm{Cu}^{2+} Z_{2}^{-} \stackrel{K_{5}}{\longleftrightarrow} \mathrm{Pd}^{2+} Z_{2}^{-}+2 \mathrm{Cu}^{+} Z^{-} \quad$ VII

$\mathrm{Cu}^{+} Z^{-}+\mathrm{O}_{2} \stackrel{K_{\mathrm{G}}}{\longleftrightarrow} Z^{-} \mathrm{Cu}^{2+} \mathrm{O}_{2}^{-} \quad$ VIII

$Z^{-} \mathrm{Cu}^{2+} \mathrm{O}_{2}^{-} \stackrel{K_{7}}{\rightleftarrows} 2 Z^{-} \mathrm{Cu}^{2+} \mathrm{O}^{-} \quad$ IX

$2 Z \mathrm{Cu}^{2+} \mathrm{O}^{-} \stackrel{K_{8}}{\rightleftarrows} Z \mathrm{Cu}^{2+}-\mathrm{O}-\mathrm{Cu}^{2+} Z+\frac{1}{2} \mathrm{O}_{2}$

$Z^{-} \mathrm{Cu}^{2+}-\mathrm{O}-\mathrm{Cu}^{2+} Z^{-}+2 \mathrm{H}_{3} \mathrm{O}^{+} Z^{-} \stackrel{K_{3}}{\longleftrightarrow} 2 \mathrm{Cu}^{2+} Z_{2}^{-}+3 \mathrm{H}_{2} \mathrm{O} \quad$ XI

С применением метода квазистационарных концентраций на основе предложенного механизма можно получить следующее уравнение для скорости образования ацетальдегида:

$$
r_{\mathrm{CH}_{3} \mathrm{CHO}}=\frac{k K_{1} K_{2} K_{3} K_{4} P_{\mathrm{H}_{2} \mathrm{O}}^{3} P_{\mathrm{C}_{2} \mathrm{H}_{4}}}{\left[\mathrm{H}_{3} \mathrm{O}^{+} Z^{-}\right]\left(1+K_{1} P_{\mathrm{H}_{2} \mathrm{O}}+K_{2} P_{\mathrm{C}_{2} \mathrm{H}_{4}}\right)+K_{2} K_{3} P_{\mathrm{H}_{2} \mathrm{O}} P_{\mathrm{C}_{2} \mathrm{H}_{4}}+K_{3} K_{4} P_{\mathrm{H}_{2} \mathrm{O}}^{2}}
$$

Для скорости образования двуокиси углерода и текущей доли поверхности, занятых ионами гидроксония предложены следующие уравнения:

$$
\begin{aligned}
& r_{\mathrm{CO}_{2}}=k_{\mathrm{I}} \frac{P_{\mathrm{CH}_{3} \mathrm{CHO}} P_{\mathrm{O}_{2}}^{\frac{1}{2}}}{P_{\mathrm{H}_{2} \mathrm{O}}^{2}} \\
& {\left[\mathrm{H}_{3} \mathrm{O}^{+} Z^{-}\right]=\left[\mathrm{H}_{3} \mathrm{O}^{+} Z^{-}\right]^{0} e^{k_{1} \mathrm{P}_{\mathrm{H} 2 \mathrm{O}}}}
\end{aligned}
$$


где $P_{i}$-парциальное давление $i$-того вещества; $k, k_{\text {п }}$ - константы скоростей образования ацетальдегида и двуокиси углерода $k=k^{0} e^{-\frac{E}{R T}}, k_{n}=k_{n}^{0} e^{-\frac{E_{n}}{R T}} ; K_{1}, K_{2}, K_{3}, K_{4}$ - константы адсорбционного равновесия элементарных стадий ${ }{ }_{\gamma}=K_{\gamma}^{0} e^{\frac{Q_{\gamma}}{R T}} ; k_{1}-$ эмпирический коэффициент, атм ${ }^{-1}$.

Уравнения (1), (2) и (3) составляют кинетическую модель рассматриваемого процесса. На основе данных приведенных в табл.1 проверено соответствие предложенного механизма экспериментальным кинетическим данным. Установлено, что при численных значениях констант, приведенных в табл. 2, кинетическая модель достаточно хорошо описывает экспериментальные данные. При этих численных значениях констант относительная погрешность экспериментальных и расчетных данных не превышала 6\%.

По аналогичному механизму протекают реакции окисления пропилена в ацетон и бутиленов в метилэтилкетон на модифицированных цеолитах [21-24]. Таким образом, методом ионного обмена синтезирована эффективная высокодисперсная каталитическая система CuPdNaY для газофазных реакций окисления низших олефинов в карбонильные соединения, которые лишены недостатков жидкофазного варианта процесса: коррозионная активность каталитических растворов и парогазовых смесей (каталитический раствор содержит соляную кислоту); образование продуктов конденсации и хлорорганических соединений; безвозвратный расход части палладия и др.

\section{Расчетные значения констант кинетической модели реакции окисления этилена}

Таблица 2

\begin{tabular}{|c|c|c|c|c|c|c|c|c|c|c|c|c|}
\hline$K^{\mathrm{o}}$ & $E$ & $K_{n}^{0}$ & $E_{\mathrm{\Pi}}$ & $K_{1}^{0}$ & $Q$ & $K_{2}^{0}$ & $Q$ & $K_{3}^{0}$ & $Q$ & $K_{4}^{0}$ & $Q_{4}$ & {$\left[\mathrm{H}_{3} \mathrm{O}^{+} Z^{-}\right]^{\mathrm{o}}$} \\
\hline 它志 & 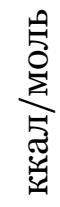 & 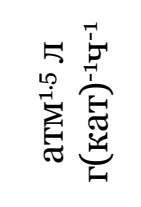 & 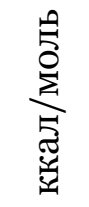 & 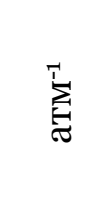 & 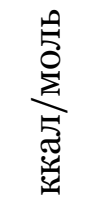 & 壳 & 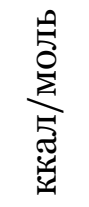 & $\underset{⿱ 亠 凶}{\mid \vec{E}}$ & 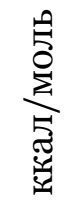 & 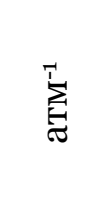 & 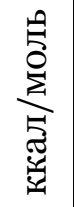 & \\
\hline $\begin{array}{c}0.238 . \\
10^{21}\end{array}$ & $\begin{array}{l}32 . \\
25\end{array}$ & $0.879 \cdot 10^{22}$ & 22.33 & $\begin{array}{c}0.9052 . \\
10^{-9}\end{array}$ & 16.48 & $\begin{array}{c}0.8071^{-} \\
10^{-8}\end{array}$ & 17.84 & $\begin{array}{c}0.155^{\circ} \\
10^{-6}\end{array}$ & 9.31 & 0.4601 & 1.0 & 0.07993 \\
\hline
\end{tabular}

\section{Парциальное окисление алифатических спиртов на цеолитных катализаторах модифицированных катионами металлов.}

Гетерогенно-каталитическое окисление алифатических спиртов относится к классу сложных многостадийных химических процессов, в результате протекания которых образуются альдегиды, кетоны, карбоновые кислоты, сложные эфиры и продукты глубокого окисления. В качестве катализаторов для этих процессов применяют металлы $(\mathrm{Cu}, \mathrm{Ag}, \mathrm{Au}$, $\mathrm{Fe}, \mathrm{Mo} \mathrm{и} \mathrm{др.),} \mathrm{оксиды} \mathrm{переходных} \mathrm{металлов} \mathrm{(} \mathrm{CuO}+\mathrm{Cu}_{2} \mathrm{O}, \mathrm{V}_{2} \mathrm{O}_{5}, \mathrm{Cr}_{2} \mathrm{O}_{3}, \mathrm{MoO}_{3}$ и др.), и смеси оксидов и соли переходных металлов (ванадаты, вольфраматы, станнаты и молибдаты цинка, кобальта, висмута и др.) [25-36]. Реакции протекают в диапазоне температур 30о$450^{\circ} \mathrm{C}$ с относительно низкой селективностью по целевому продукту.

Методом ИК-спектроскопии выявлена роль бренстедовских кислотных центров оксидных катализаторов $\left(\mathrm{Cr}-\mathrm{Mo}-\mathrm{O}, \mathrm{MoO}_{3}\right)$ в гетерогенном парциальном окислении алифатических спиртов [37]. Авторами этой работы установлено, что аналогично жидкофазному варианту процесса, который протекает в кислотной среде с участием протонов через образование промежуточного соединения хромат эфира, при гетерогенном парциальном окислении также образуются поверхностные типы алкоксидов, которые формируются при взаимодействии бренстедовских кислотных центров средней силы с адсорбированными на поверхности катализатора молекулами алифатических спиртов. Реакция гетерогенного парциального окисления алифатических спиртов протекает в 
результате взаимодействия этих алкоксидных образований с поверхностным нуклеофильным кислородом.

Разработка эффективных способов получения альдегидов, карбоновых кислот и сложных эфиров окислением низших алифатических спиртов, представляет не только практический, но и теоретический интерес, обусловленный тем, что в литературе отсутствуют работы, посвященные подбору активного модифицированного цеолитного катализатора и изучению механизма и кинетических закономерностей реакций окисления алифатических спиртов на этих катализаторах.

Результаты наших исследований за последние 30 лет по разработке цеолитных катализаторов для реакций окисления алифатических спиртов, послужили основой для создания принципов конструирования высокоэффективных полифункциональных модифицированных цеолитных катализаторов для этих реакций на основе известных каталитических свойств переходных металлов и физико-химических свойств цеолитов.

Выявлено, что природные и синтетические цеолиты, модифицированные катионами меди и палладия методом ионного обмена проявляют высокую активность и селективность в реакциях парциального окисления метилового, этилового, $\boldsymbol{H}$-пропилового, изопропилового, н-бутилового, изобутилового, втор-бутилового и изоамилового спиртов в альдегиды, кетоны, карбоновые кислоты и сложные эфиры карбоновых кислот [38-70]. В результате проведенных исследований установлено, что суммарную схему протекания реакций парофазного окисления низших алифатических спиртов на модифицированных цеолитных катализаторах можно представить в следующем виде:

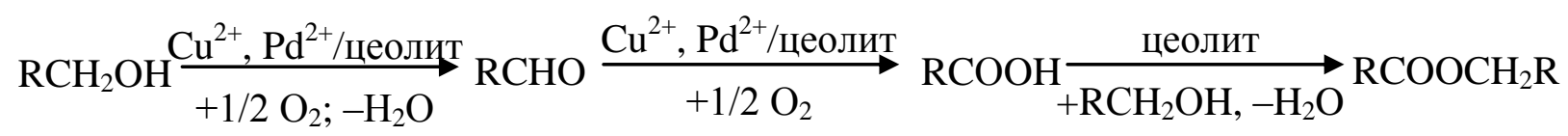

Для всех трех стадий этого механизма одним из активных адсорбционных центров являются бренстедовские кислотные центры. Известно, что парофазная этерификация уксусной кислоты этиловым спиртом протекает на цеолитных катализаторах с бренстедовскими кислотными центрами средней силы [71-73].

С целью разработки принципов конструирования активных катализаторов для реакций окислительного превращения алифатических спиртов нами исследована каталитическая активность около 40 разных цеолитов (включая их водородные формы и разные силикатные модули) в реакции парофазной этерификации уксусной кислоты этиловым спиртом. В табл.3 представлены результаты исследований каталитической активности некоторых из этих цеолитов в реакции парофазной этерификации уксусной кислоты этиловым спиртом в этилацетат.

Таблица 3

\section{Результаты исследований реакции парофазной этерификации уксусной кислоты этиловым спиртом на цеолитных катализаторах $\left(\mathrm{C}_{2} \mathrm{H}_{5} \mathrm{OH}: \mathrm{CH}_{3} \mathrm{COOH}=1: 2\right)$}

\begin{tabular}{|c|c|c|c|c|c|c|c|}
\hline \multirow[b]{2}{*}{ № } & \multirow[b]{2}{*}{ Катализатор } & \multirow[b]{2}{*}{$\mathrm{T},{ }^{\circ} \mathrm{C}$} & \multirow{2}{*}{$\begin{array}{c}\text { Объём } \\
\text { ная } \\
\text { скорос } \\
\text { ть, ч }{ }^{-1} \\
\end{array}$} & \multicolumn{3}{|c|}{ Выход \% } & \multirow{2}{*}{$\begin{array}{c}\text { Степень } \\
\text { превращения } \\
\text { спирта, \% }\end{array}$} \\
\hline & & & & $\begin{array}{c}\mathrm{CH}_{3} \mathrm{COOC}_{2} \\
\mathrm{H}_{5}\end{array}$ & $\begin{array}{c}\left(\mathrm{C}_{2} \mathrm{H}_{5}\right)_{2} \\
\mathrm{O}\end{array}$ & $\mathrm{C}_{2} \mathrm{H}_{4}$ & \\
\hline 1 & \multirow{2}{*}{ H-Clin.(o.1 N HCl) } & 200 & 3.0 & 83.7 & 3.5 & 5.1 & 92.3 \\
\hline 2 & & 250 & 3.0 & 84.9 & 4.0 & 7.8 & 96.7 \\
\hline 3 & $\begin{array}{c}\text { H-MOR } \\
\text { (синтетический, ДК) }\end{array}$ & 200 & 5.0 & 72.5 & - & 0.5 & 73.0 \\
\hline 4 & $\begin{array}{c}\text { H-MOR (природный, } \\
\text { ДА) }\end{array}$ & 260 & 15.0 & 82.9 & - & 0.2 & 83.1 \\
\hline 5 & $\begin{array}{c}\text { H-MOR } \\
\text { (синтетический, ДА) }\end{array}$ & 180 & 15.0 & 88.4 & - & - & 88.4 \\
\hline 6 & $\mathrm{NaHY}$ & 240 & 7.5 & 95.2 & - & 2.8 & 98.0 \\
\hline
\end{tabular}




\begin{tabular}{|c|c|c|c|c|c|c|c|}
\hline 7 & \multirow{2}{*}{$\beta$-цеолит ( $\alpha=25)$} & 160 & 7.9 & 94.6 & - & - & 94.6 \\
\hline 8 & & 200 & 13.8 & 96.4 & - & - & 96.4 \\
\hline 9 & \multirow{2}{*}{ HZSM-5 ( $\alpha=25)$} & 180 & 12.1 & 94.7 & - & - & 94.7 \\
\hline 10 & & 200 & $3 \cdot 3$ & 89.2 & 2.0 & - & 91.2 \\
\hline 11 & \multirow{2}{*}{$\operatorname{HZSM}-5(\alpha=50)$} & 160 & 11.2 & 98.0 & - & - & 98.0 \\
\hline 12 & & 200 & 7.8 & 95.6 & - & - & 95.6 \\
\hline
\end{tabular}

На всех изученных нами цеолитах экспериментально исследованы кинетические закономерности протекания парофазной этерификации уксусной кислоты этиловым спиртом в этилацетат. С использованием экспериментальных кинетических данных и кинетического уравнения реакции парофазной этерификации уксусной кислоты этиловым спиртом в этилацетат [74, 75]

$$
r=\frac{k K_{2} P_{1} P_{2}}{\left(1+K_{2} P_{2}\right)^{2}}
$$

где, $\mathrm{k}, \mathrm{K}$ - константа скорости и константа адсорбционного равновесия; $\mathrm{P}_{1}, \mathrm{P}_{2}-$ парциальные давления спирта и уксусной кислоты, соответственно, путём сравнительного анализа численных значений предэкспоненциальных множителей констант скоростей, $\mathrm{k}$ (энергия активации этой реакции на всех изученных цеолитах $\mathrm{E}=19.5$ ккал/моль) составлен ряд каталитической активности для изученных цеолитов в рассмотриваемой реакции. По каталитической активности цеолиты разделены на 3 группы. Цеолиты, входящие в первую группу проявляют относительно высокую каталитическую активность в реакции парофазной этерификации уксусной кислоты этиловым спиртом в этилацетат. Численные значения предэкспоненциальных множителей констант скоростей при протекании реакции на этих цеолитах на один и два порядка превышает численные значения предэкспоненциальных множителей констант скоростей при протекании реакции на цеолитах второй и третьей групп, соответственно.

Ниже представлен ряд каталитической активности цеолитов в реакции парофазной этерификации уксусной кислоты этиловым спиртом в этилацетат:

$\beta$-цеолит $>$ HZSM-5>H-MOR(син.) $>$ NaHY $>$ H-MOR (природ.) $>$ CaA $>$ H-MOR.(синт. DK.) $>$ H-clin. $($ DA) $>$ CaY $>$ LiY
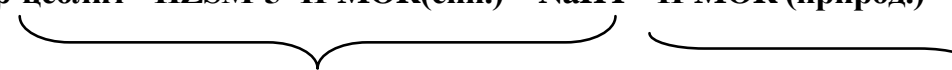

I

II

III

Установлено, что цеолиты, проявляющие относительно высокую каталитическую активность в реакции этерификации при модификации ионами $\mathrm{Pd}^{2+}$ и $\mathrm{Cu}^{2+}$ методом ионного обмена являются активными и селективными катализаторами для реакций парциального окисления низших спиртов в соответствующие альдегиды и кетоны [9, 76]. Цеолиты со средней каталитической активностью в реакции этерификации (цеолиты II группы) при модификации ионами $\mathrm{Pd}^{2+}$ и $\mathrm{Cu}^{2+}$ проявляют высокую активность и селективность в реакциях парциального окисления низших алифатических спиртов в соответствующие карбоновые кислоты $[8,40,78]$. Цеолиты, проявляющие относительно слабую каталитическую активность в реакции парофазной этерификации (цеолиты III группы) после модификации ионами $\mathrm{Pd}^{2+}$ и $\mathrm{Cu}^{2+}$ становятся активными и селективными катализаторами в реакции окислительного превращения низших алифатических спиртов в соответствующие сложные эфиры [43, 49, 79].

Таким образом, каталитическая активность цеолитов в реакции парофазной этерификации уксусной кислоты этиловым спиртом является показателем оптимального распределения бренстедовских кислотных центров по их силе на поверхности цеолита для рассматриваемой реакции.

Роль поверхностных кислотных центров в реакции парциального окисления низших алифатических спиртов на модифицированных цеолитных катализаторах нами изучена на примере парциального окисления изоамилового спирта в изовалериановый альдегид на 
катализаторе $\mathrm{CuPdCaA} \mathrm{путем} \mathrm{обработки} \mathrm{катализатора} \mathrm{разными} \mathrm{количествами} \mathrm{пиридина,}$ который блокирует кислотные центры [6о]. Установлено, что обработка катализатора пиридином в количестве 60 мл в 4 раза уменьшает выход изовалерианового альдегида.

Методом ЭПР нами исследована роль ионов меди в реакциях парциального окисления алифатических спиртов на примере парциального окисления $н$-пропилового спирта [9]. Установлено, что медь участвует в реакции реокисления частично восстановленных ионов палладия. Кроме того, при парциальном окислении алифатических спиртов с участием меди образуются дополнительные бренстедовские кислотные центры, необходимые для протекания целевой реакции.

Экспериментально исследована также роль ионов палладия в реакции парциального окисления алифатических спиртов на модифицированных цеолитных катализаторах методом восстановления ионов палладия водородом до металлического состояния. Установлено, что восстановление ионов палладия до металлического состояния приводит к увеличению скорости глубокого окисления. Ионы палладия участвуют в образовании поверхностных нуклеофильных кислородов [5].

Нами также методом ИК-спектроскопии на примере реакции парциального окисления нпропилового спирта на катализаторе $\mathrm{CuCaA}$, выявлено образование поверхностных типов алкоксидов, которые формируются при взаимодействии бренстедовских кислотных центров поверхности модифицированного цеолита с адсорбированными на его поверхности молекулами н-пропилового спирта [9].

Таким образом, на основе анализа литературных материалов и собственных экспериментальных данных предложен стадийный механизм для реакций парциального окисления низших алифатических спиртов на модифицированных цеолитных катализаторах:

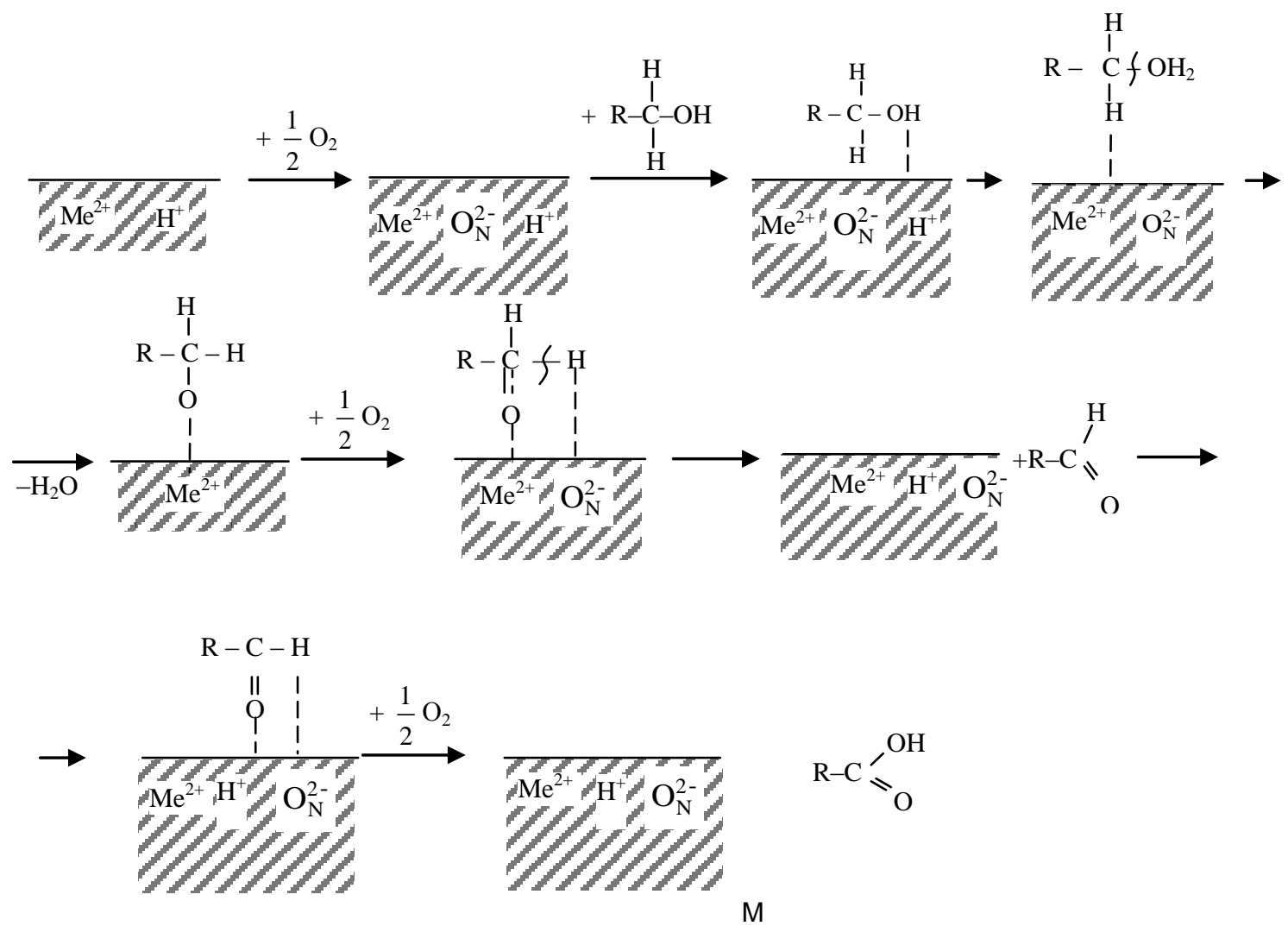

Предполагая элементарность стадий в условиях стационарности $\mathrm{r}_{1}=\mathrm{r}_{2}=\mathrm{r}_{3}=\mathrm{r}_{4}$ и постоянства общего числа поверхностных участков $\sum \theta_{\mathrm{i}}=1$, уравнения для скорости образования карбоновой кислоты и альдегида или кетона, полученные на основе вышеприведенного механизма имеют следующий вид: 


$$
\begin{gathered}
r_{\text {кисл }}=k_{1} P_{\mathrm{O}_{2}}\left[\frac{\sqrt{1-4\left(\frac{k_{1} P_{\mathrm{O}_{2}}}{k_{2} P_{\mathrm{c \Pi}}}+\frac{k_{1} P_{\mathrm{O}_{2}}}{k_{3}}\right)\left(\frac{k_{2}}{k_{4}} P_{\mathrm{c \Pi}}-1\right)}-1}{2\left(\frac{k_{1} P_{\mathrm{O}_{2}}}{2 k_{2} P_{\mathrm{c \Pi}}}+\frac{k_{1} P_{\mathrm{O}_{2}}}{2 k_{3}}\right)}\right]^{2} \\
r_{\text {альд }}=k_{1} P_{\mathrm{O}_{2}}\left[\frac{\sqrt{1+4\left(\frac{k_{1} P_{\mathrm{O}_{2}}}{2 k_{2} P_{c n}}+\frac{k_{1} P_{\mathrm{O}_{2}}}{2 k_{3}}\right)}-1}{2\left(\frac{k_{1} P_{\mathrm{O}_{2}}}{2 k_{2} P_{c n}}+\frac{k_{1} P_{\mathrm{O}_{2}}}{2 k_{3}}\right)}\right]^{2}
\end{gathered}
$$
Сложные эфиры образуются на
модифицированного цеолита по механизму [9]:

$\mathrm{R}_{1} \mathrm{OH}+Z \underset{\mathrm{K}_{\mathrm{l}}}{\rightleftarrows} Z \mathrm{R}_{1} \mathrm{OH}$

$\mathrm{R}_{2} \mathrm{COOH}+Z \underset{\mathrm{R}_{2}}{\stackrel{K_{2}}{\rightleftarrows}} Z \mathrm{R}_{2} \mathrm{COOH}$
$Z \mathrm{R}_{1} \mathrm{OH}+Z \mathrm{R}_{2} \mathrm{COOH} \underset{k^{*}}{\longrightarrow} 2 Z+\mathrm{R}_{2}-\mathrm{C}-\mathrm{O}-\mathrm{I}_{1}+\mathrm{H}_{2} \mathrm{O}$.

Уравнение скорости образования эфира, соответствующее этому механизму имеет вид:

$$
r_{\ni}=\frac{k * K_{1} K_{2} P_{\text {сп }} P_{\text {кисл }}}{\left(1+K_{1} P_{\text {сп }}+K_{2} P_{\text {кисл }}\right)^{2}}=\frac{k K_{2} P_{\text {сп }} P_{\text {кисл }}}{\left(1+K_{1} P_{\text {сп }}+K_{2} P_{\text {кисл }}\right)^{2}},
$$

где $k^{*} K_{1}=k$, так как $K_{2}>>K_{1}$,

$$
r_{\ni}=\frac{k K_{2} P_{\text {сп }} P_{\text {кисл }}}{\left(1+K_{2} P_{\text {кисл }}\right)^{2}} \cdot
$$

Уравнения (4), (5) и (6) составляют общую кинетическую модель парциального окисления низших алифатических спиртов на модифицированных цеолитных катализаторах.

Проверка применимости общей методики конструирования цеолитных катализаторов, а также предложенного общего стадийного механизма парциального окисления низших алифатических спиртов на модифицированных цеолитных катализаторах осуществлена на примере реакции парциального окисления втор-бутилового спирта в метилэтилкетон [62]. На основе экспериментальных исследований установлено, что цеолит I группы, $\mathrm{NaY}$ модифицированный ионами; $\mathrm{Cu}^{2+}-2.0$ мас.\%, $\mathrm{Pd}^{2+}-0.1$ мас.\% и $\mathrm{Zn}-4.0$ мас.\% (CuPdZnNaY) проявляет высокую каталитическую активность в реакции парциального окисления вторбутилового спирта в метилэтилкетон. Результаты экспериментального исследования кинетических закономерностей этой реакции на катализаторе $\mathrm{CuPdZnNaY}$ представлены в табл. 4.

\section{Экспериментальные кинетические данные для реакции парциального окисления втор-бутилового спирта в метилэтилкетон на катализаторе CuPdZnNaY}

\begin{tabular}{|c|c|c|c|c|c|c|c|}
\hline \multirow{2}{*}{$\mathrm{T},{ }^{\circ} \mathrm{C}$} & \multirow{2}{*}{$\begin{array}{c}\text { Объёмная } \\
\text { скорость, } \\
\end{array}$} & $P_{c n}^{0}$, атм. & $P_{O_{2}}^{0}$, атм. & \multirow{2}{*}{$\begin{array}{c}\text { Степень } \\
\text { превращения }\end{array}$} & & \multicolumn{3}{|c|}{ Выход,\% } \\
\cline { 5 - 8 } & & & $\mathrm{C}_{4} \mathrm{H}_{8} \mathrm{O}$ & $\mathrm{C}_{4} \mathrm{H}_{8}$ & $\mathrm{CO}_{2}$ \\
\hline 310 & 2500 & 0,12 & 0.16 & 94.6 & 81.3 & 12.2 & 1.1 \\
\hline 310 & 2500 & 0.24 & 0.16 & 93.3 & 87.1 & 4.3 & 1.9 \\
\hline 310 & 2500 & 0,28 & 0.16 & 91.8 & 86.5 & 2.5 & 2.3 \\
\hline 310 & 2500 & 0,36 & 0.16 & 85.6 & 81.8 & 0.2 & 3.6 \\
\hline 310 & 2500 & 0.24 & 0.12 & 86.1 & 82.8 & 2.1 & 1.2 \\
\hline 310 & 2500 & 0.24 & 0.2 & 95.0 & 85.5 & 6.8 & 3.2 \\
\hline 310 & 2500 & 0.24 & 0.24 & 95.5 & 82.4 & 7.9 & 5.2 \\
\hline 280 & 2500 & 0.24 & 0.16 & 76.4 & 75.2 & 0.7 & 0.2 \\
\hline
\end{tabular}




\begin{tabular}{|l|l|l|l|l|l|l|l|}
\hline 300 & 2500 & 0.24 & 0.16 & 87.4 & 82.4 & 4.5 & 0.5 \\
\hline 320 & 2500 & 0.24 & 0.16 & 92.8 & 86.4 & 5.2 & 1.2 \\
\hline 300 & 2000 & 0.24 & 0.16 & 97.7 & 89.4 & 3.7 & 4.6 \\
\hline 300 & 3000 & 0.24 & 0.16 & 86.4 & 85.9 & 2.7 & 1.8 \\
\hline 300 & 4000 & 0.24 & 0.16 & 78.1 & 76.9 & 0.7 & 0.5 \\
\hline
\end{tabular}

На основе экспериментальных данных составлена кинетическая схема протекания реакций парциального окисления втор-бутилового спирта в метилэтилкетон.

$$
\begin{aligned}
& \text { (7) } k_{4} \prod_{+\mathrm{O}_{2}}^{\mathrm{CO}_{2}} \\
& \mathrm{CH}_{3}-\mathrm{CH}(\mathrm{OH})-\mathrm{CH}_{2}-\mathrm{CH}_{3} \stackrel{\mathrm{k}_{1}}{\longrightarrow} \mathrm{CH}_{3}-\mathrm{CO}-\mathrm{CH}_{2}-\mathrm{CH}_{3}+\mathrm{H}_{2} \mathrm{O} \\
& k_{\mathrm{C}_{4} \mathrm{H}_{8}+\mathrm{H}_{2} \mathrm{O}}
\end{aligned}
$$

Согласно общему стадийному механизму парциального окисления низших алифатических спиртов для скорости образования метилэтилкетона было принято уравнение (5).

Диоксид углерода образуется при взаимодействии слабо адсорбированных молекул втор-бутилового спирта с адсорбированными молекулами кислорода согласно механизму Ленгмюра-Хиншельвуда. Кинетическое уравнение соответствующее этому механизму имеет вид:

$$
r_{\mathrm{CO}_{2}}=\frac{k_{4} K_{1} K_{2} P_{\mathrm{O}_{2}} P_{\text {сп }}}{\left(1+K_{1} P_{\mathrm{O}_{2}}+K_{2} P_{\text {сп }}\right)^{2}}
$$

Бутилены образуются в результате дегидратации втор-бутилового спирта, которая является обратимой реакцией. С учетом торможения скорости реакции адсорбированными молекулами спирта и воды, наблюдаемая скорость реакции имеет вид:

$$
r_{\mathrm{C}_{4} \mathrm{H}_{8}}=K_{5} \frac{P_{\mathrm{c \Pi}}-\frac{1}{K_{p}} P_{\mathrm{C}_{4} \mathrm{H}_{8}} P_{\mathrm{H}_{2} \mathrm{O}}}{K_{3} P_{\mathrm{cn}}+K_{4} P_{\mathrm{H}_{2} \mathrm{O}}}
$$

Уравнения (5), (8) и (9) составляют кинетическую модель процесса окисления вторбутилового спирта.

Численные значения констант кинетической модели, рассчитанные на основе экспериментальных кинетических данных представлены в табл. 5 .

Таблица 5

\section{Кинетические параметры модели реакции окисления бутанола-2 в метилэтилкетон}

\begin{tabular}{|c|l|l|l|}
\hline \multicolumn{2}{|c|}{$\ln k_{i}^{0}\left(\ln K_{i}^{0}\right)$} & \multicolumn{2}{|c|}{$E_{\mathrm{i}},\left(\mathrm{Q}_{\mathrm{i}}\right)$, ккал/моль } \\
\hline $\ln k_{1}^{0}$ & 7,19 & $E_{1}$ & 5,15 \\
\hline $\ln k_{2}^{0}$ & 4,03 & $E_{2}$ & 6,47 \\
\hline $\ln k_{3}^{0}$ & 7,67 & $E_{3}$ & 5,28 \\
\hline $\ln k_{4}^{0}$ & 2,09 & $E_{4}$ & 2,13 \\
\hline $\ln k_{5}^{0}$ & 9,98 & $E_{5}$ & 1,64 \\
\hline $\ln K_{1}^{0}$ & 3,21 & $\mathrm{Q}_{1}$ & 1,98 \\
\hline $\ln K_{2}^{0}$ & 4,08 & $\mathrm{Q}_{2}$ & 4,00 \\
\hline $\ln K_{3}^{0}$ & 4,67 & $\mathrm{Q}_{3}$ & 1,50 \\
\hline $\ln K_{4}^{0}$ & 4,54 & $\mathrm{Q}_{4}$ & 4,19 \\
\hline
\end{tabular}


При численных значениях констант кинетической модели, приведенных в табл. 3, относительная погрешность экспериментальных данных не превышал 10 \%.

Аналогичные исследования проведены для реакций парциального окисления метилового, этилового, $\boldsymbol{H}$-пропилового, изопропилового, бутилового, изобутилового и изоамилового спиртов на модифицированных цеолитных катализаторах $[44,57,60,77,81]$ с целью получения соответствующих альдегидов и кетонов.

С использованием цеолитов второй группы в ряде каталитической активности в реакции парофазной этерификации уксусной кислоты этиловым спиртом в этилацетат синтезированы активные и селективные металлцеолитные катализаторы для парциального окисления алифатических спиртов в соответствующие карбоновые кислоты; $\mathrm{CuCaA}$ (содержащий 3.0 мас.\% $\mathrm{Cu}^{2+}$ ) - для окисления н-пропилового спирта в пропионовую кислоту [39]; Pd-морденит (содержащий 0.1 мас.\% $\mathrm{Pd}^{2+}$ ) - для окисления метанола в муравьиную кислоту [45] и окисления изобутилового спирта в изомасляную кислоту [65].

В табл. 6 представлены результаты экспериментального исследования реакции парциального окисления н-пропилового спирта пропионовую кислоту.

На основе цеолитов III группы синтезированы активные и селективные металлцеолитные катализаторы для реакций окисления алифатических спиртов в сложные

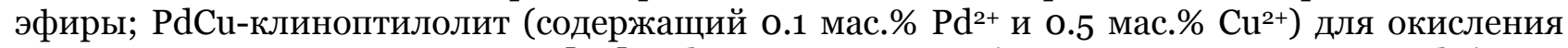
этилового спирта в этилацетат [49], Pd-клиноптилолит (содержащий 0.1 мас.\% $\mathrm{Pd}^{2+}$ ) для окисления пропилового спирта в пропилпропионат [9] и др.

Таблица 6

\section{Экспериментальные кинетические данные для реакции парциального окисления н-пропилового спирта в пропионовую кислоту на катализаторе CuCaA}

\begin{tabular}{|c|c|c|c|c|c|c|c|c|c|c|}
\hline \multirow[b]{2}{*}{$\mathrm{T},{ }^{\mathrm{o}} \mathrm{C}$} & \multirow{2}{*}{$\begin{array}{c}\text { Объём- } \\
\text { ная } \\
\text { скорость, } \\
\text { ч-1 }^{-1}\end{array}$} & \multirow{2}{*}{$\begin{array}{c}n_{\mathrm{C}_{3} \mathrm{H}_{7} \mathrm{OH}}^{0} \\
\text { моль } \\
\quad \text { ч } \\
\text { с }\end{array}$} & \multirow{2}{*}{$\begin{array}{c}n_{\mathrm{O}_{2}}^{0} \\
\text { моль/ч } \\
\text { ac }\end{array}$} & \multirow{2}{*}{$\begin{array}{c}n_{\mathrm{N}_{2}}^{0} \\
\text { моль/ч } \\
\text { ac }\end{array}$} & \multirow{2}{*}{$\begin{array}{c}\text { Степень } \\
\text { превраще } \\
\text { ния } \\
\text { спирта, \% }\end{array}$} & \multicolumn{5}{|c|}{ Выход продуктов реакции,\% } \\
\hline & & & & & & $\begin{array}{c}\mathrm{C}_{2} \mathrm{H}_{5} \mathrm{C} \\
\mathrm{HO}\end{array}$ & $\begin{array}{c}\mathrm{C}_{2} \mathrm{H}_{5} \mathrm{CO} \\
\mathrm{OH}\end{array}$ & $\begin{array}{c}\mathrm{C}_{2} \mathrm{H}_{5} \mathrm{COOC} \\
{ }_{3} \mathrm{H}_{7}\end{array}$ & $\mathrm{CO}_{2}$ & $\begin{array}{l}\mathrm{C}_{3} \\
\mathrm{H}_{6}\end{array}$ \\
\hline 180 & 1200 & 0.0049 & 0.0297 & 0.0645 & 91.4 & 19.5 & 35.2 & 25.1 & 9.6 & 1.7 \\
\hline 180 & 1200 & 0.0198 & 0.0297 & 0.0496 & 66.4 & 12.1 & 36.7 & 13.6 & 3.5 & 0.5 \\
\hline 190 & 1200 & 0.0099 & 0.0297 & 0.0595 & 86.4 & 18.8 & 49.0 & 10.9 & 7.0 & 0.7 \\
\hline 190 & 1200 & 0.0297 & 0.0297 & 0.0397 & 39.3 & - & 27.5 & 6.8 & 4.5 & 0.5 \\
\hline 200 & 1200 & 0.0049 & 0.0297 & 0.0645 & 98.1 & 24.3 & 47.3 & 14.3 & 11.2 & 1.0 \\
\hline 225 & 1200 & 0.0099 & 0.0297 & 0.0595 & 97.8 & 11.0 & 66.4 & 5.7 & 14.2 & 0.5 \\
\hline 225 & 1200 & 0.0297 & 0.0297 & 0.0397 & 56.1 & - & 44.3 & 4.0 & 7.5 & 0.3 \\
\hline 250 & 1200 & 0.0397 & 0.0297 & 0.0297 & 45.0 & - & 32.3 & 1.6 & 11.0 & 0.1 \\
\hline 190 & 1200 & 0.0099 & 0.0397 & 0.0496 & 97.8 & 20.6 & 57.6 & 9.9 & 9.1 & 0.6 \\
\hline 200 & 1200 & 0.0099 & 0.0297 & 0.0595 & 96.3 & 19.8 & 57.6 & 9.8 & 8.5 & 0.6 \\
\hline 225 & 1200 & 0.0099 & 0.0198 & 0.0694 & 80.7 & 9.7 & 51.5 & $7 \cdot 3$ & 11.4 & 0.8 \\
\hline 200 & 900 & 0.0074 & 0.0223 & 0.0446 & 98.1 & 12.2 & 66.2 & 8.4 & 10.3 & 1.0 \\
\hline 225 & 900 & 0.0074 & 0.0223 & 0.0446 & 98.3 & 3.2 & 72.9 & 4.6 & 16.1 & 1.5 \\
\hline 200 & 2000 & 0.0165 & 0.0496 & 0.0992 & 84.2 & 10.5 & 52.3 & 13.5 & 7.5 & 0.4 \\
\hline 225 & 2000 & 0.0165 & 0.0496 & 0.0992 & 97.0 & 7.0 & 62.8 & 10.0 & 16.4 & 0.8 \\
\hline 240 & 3000 & 0.0165 & 0.0496 & 0.0992 & 92.5 & 3.7 & 46.0 & 22.9 & 19.7 & 0.2 \\
\hline 250 & 4500 & 0.0372 & 0.1116 & 0.2231 & 66.5 & 2.0 & 20.5 & 26.2 & 17.7 & 0.1 \\
\hline
\end{tabular}

В табл. 7 представлены результаты экспериментального исследования реакции окисления н-пропилового спирта в пропилпропионат на катализаторе Pd-клиноптилолит. 
Экспериментальные результаты для реакции окисления н-пропилового спирта в пропилпропионат на катализаторе Рd-клиноптилолит

\begin{tabular}{|c|c|c|c|c|c|c|c|c|}
\hline \multirow[b]{2}{*}{$\mathrm{T},{ }^{\circ} \mathrm{C}$} & \multirow{2}{*}{$\begin{array}{l}\text { Объёмная } \\
\text { скорость, } \\
\mathbf{ч}^{-1}\end{array}$} & \multirow{2}{*}{$\begin{array}{c}\text { Мольное } \\
\text { соотношение } \\
\mathrm{C}_{3} \mathrm{H}_{7} \mathrm{OH}: \mathrm{O}_{2}: \mathrm{N}_{2}\end{array}$} & \multirow{2}{*}{$\begin{array}{c}\text { Степень } \\
\text { превращения } \\
\text { спирта, \% }\end{array}$} & \multicolumn{5}{|c|}{ Выход продуктов реакции,\% } \\
\hline & & & & $\begin{array}{c}\mathrm{C}_{2} \mathrm{H}_{5} \mathrm{CH} \\
\mathrm{O}\end{array}$ & $\begin{array}{c}\mathrm{C}_{2} \mathrm{H}_{5} \mathrm{COO} \\
\mathrm{H}\end{array}$ & $\mathrm{C}_{2} \mathrm{H}_{5} \mathrm{COOC}_{3} \mathrm{H}_{7}$ & $\mathrm{CO}_{2}$ & $\mathrm{C}_{3} \mathrm{H}_{6}$ \\
\hline 190 & 700 & 0.1:0.3:0.6 & 81.1 & 16.1 & - & 65.0 & - & - \\
\hline 190 & 700 & $0.1: 0.35: 0.55$ & 93.3 & 6.3 & - & 85.3 & 1.0 & 0.7 \\
\hline 200 & 700 & $0.1: 0.35: 0.55$ & 94.0 & 4.9 & 3.1 & 82.9 & 1.9 & 1.2 \\
\hline 220 & 700 & $0.1: 0.35: 0.55$ & 95.0 & 3.0 & 6.1 & 81.9 & 2.1 & 1.9 \\
\hline 190 & 700 & $0.1: 0.4: 0.5$ & 94.0 & 4.2 & 4.8 & 75.8 & 6.9 & 2.3 \\
\hline 200 & 700 & $0.1: 0.4: 0.5$ & 93.8 & 3.0 & 7.8 & 72.6 & 7.6 & 2.8 \\
\hline 200 & 1400 & $0.1: 0.35: 0.55$ & 92.2 & 8.6 & 2.8 & 78.2 & 1.6 & 1.0 \\
\hline 200 & 2800 & $0.1: 0.35: 0.55$ & 85.0 & 14.4 & 1.3 & 68.4 & 0.9 & - \\
\hline 220 & 2800 & $0.1: 0.35: 0.55$ & 92.0 & 18.9 & 2.3 & 66.1 & 2.9 & 1.8 \\
\hline 220 & 3500 & $0.1: 0.35: 0.55$ & 87.8 & 23.4 & 1.0 & 61.8 & 1.7 & - \\
\hline
\end{tabular}

На всех изученных металлцеолитных катализаторах исследованы кинетические закономерности окисления алифатических спиртов и с использованием кинетических уравнений (4), (5) и (6) составлены кинетические модели процессов.

Таким образом, доказана применимость предложенного общего стадийного механизма ко всем реакциям парциального окисления низших алифатических спиртов на модифицированных цеолитных катализаторах.

Сравнительный анализ литературных данных по парциальному окислению низших алифатических спиртов на нанесенных металлических и оксидных катализаторах с данными, полученными при протекании реакций на модифицированных цеолитных катализаторах, показывает на высокую эффективность цеолитных катализаторов. Из-за физико-химических особенностей цеолитов, а также высокой дисперсности активного компонента катализатора реакция парциального окисления низших алифатических спиртов на модифицированных цеолитных катализаторах протекает при относительно низких температурах с высокой селективностью.

Селективное окислительное дегидрирование нафтеновых углеводородов на металлсодержащих цеолитных катализаторах.

Алициклические диеновые углеводороды являются исходным сырьём для синтеза различных классов полифункциональных веществ. Функциональные производные этих соединений в связи с высокой активностью кратной связи используются в синтезе полимерных и композиционных материалов специального назначения, физиологически активных соединений, а также хиральных синтонов для направленного получения аналогов природных соединений и лекарственных препаратов. Одно из перспективных направлений производства циклических непредельных углеводородов - одностадийное каталитическое превращение нафтеновых углеводородов, ресурсы которых в нефтях и продуктах их переработки весьма значительны. Наиболее широко исследована реакция каталитического дегидрирования нафтеновых углеводородов в бескислородном режиме [82-85]. Известно, что это - реакция, ограниченная термодинамически, осуществляется в жёстких условиях, приводящих к ароматизации и осмолению значительной части углеводородной фракции, а также быстрому закоксовыванию и дезактивации применяемых катализаторов. Использование в качестве акцепторов водорода молекулярного кислорода позволяет провести процесс в более мягких условиях и предотвратить вышеуказанные осложнения.

Каталитические свойства цеолитных катализаторов в реакции окисления циклогексана исследовались в работе [86]. Было установлено, что на фожазитах в основном протекают реакции глубокого и окислительного дегидрирования с образованием диоксида углерода и бензола. Узкопористые цеолиты (содалит, шабазит, эрионит, морденит, клиноптилолит и натролит) проявляют селективность в образовании циклогексена по следующей схеме: 


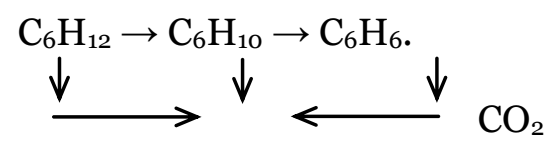

Как видно из схемы, промежуточный продукт процесса окисления циклогексана циклогексадиен 1,3 на изученных цеолитах не образуется.

В работе [10] приведены результаты экспериментальных исследований по подбору активного катализатора для реакции окислительного дегидрирования циклогексана в циклогексадиен-1,3. В результате этих исследований было установлено, что катализатор $\mathrm{CuZnCoCr-клиноптилолит,} \mathrm{содержащий} \mathrm{Cu}^{2+}-0.5 \% ; \quad \mathrm{Zn}^{2+}-0.2 \% ; \quad \mathrm{Co}^{2+}-0.1 \% ; \quad \mathrm{Cr}^{3+}-0.1 \%$ проявляет относительно высокую активность в рассматриваемой реакции. Были изучены кинетические закономерности протекания реакции на активном катализаторе [87]. По полученным экспериментальным данным предложена следующая кинетическая схема протекания реакции окислительного дегидрирования циклогексана на металлцеолитном катализаторе $\mathrm{CuZnCoCr-клиноптилолит:}$

Предположим: циклогексен образуется при взаимодействии адсорбированных молекул циклогексана с диссоциативно адсорбированными молекулами кислорода. Тогда согласно механизму Ленгмюра-Хиншельвуда кинетическое уравнение для этой реакции имеет вид:

$$
n=\frac{k_{1} K_{1} P \sqrt{K_{2} P_{2}}}{\left(1+K_{1} P+\sqrt{K_{2} P_{2}}+K_{3} P_{3}+K_{4} P_{4}+K_{5} P_{5}+K_{6} P_{2}\right)^{2}}
$$

Циклогексадиен-1,3 образуется при взаимодействии адсорбированных молекул циклогексена с диссоциативно адсорбированными молекулами кислорода. Кинетическое уравнение соответствующее этому механизму

$$
r_{2}=\frac{k_{2} K_{3} P_{3} \sqrt{K_{2} P_{2}}}{\left(1+K_{1} P_{1}+\sqrt{K_{2} P_{2}}+K_{3} P_{3}+K_{4} P_{4}+K_{5} P_{5}+K_{6} P_{2}\right)^{2}}
$$

Образование $\mathrm{CO}_{2}$ протекает при взаимодействии адсорбированных молекул циклогексена и кислорода. Этому механизму соответствует кинетическое уравнение:

$$
r_{3}=\frac{k_{7} K_{3} P_{3} K_{6} P_{2}}{\left(1+K_{1} P_{1}+\sqrt{K_{2} P_{2}}+K_{3} P_{3}+K_{4} P_{4}+K_{5} P_{5}+K_{6} P_{2}\right)^{2}}
$$

Реакция образования циклогексанола происходит между адсорбированной молекулой циклогексена и молекулой воды из газовой фазы. Кинетическое уравнение соответствующее этому механизму

$$
r_{4}=\frac{k_{6} K_{3} P_{3} P_{6}}{\left(1+K_{1} P_{1}+\sqrt{K_{2} P_{2}}+K_{3} P_{3}+K_{4} P_{4}+K_{5} P_{5}+K_{6} P_{2}\right)}
$$

Согласно кинетической схеме (1) суммарную скорость образования циклогексена можно представить в следующем виде:

$$
r_{C_{6} H_{10}}=r_{1}-r_{2}-r_{3}-r_{4}
$$


Глубокое окисление циклогексадиена-1,3 происходит при взаимодействии адсорбированных молекул циклогексадиена и кислорода и образование бензола при взаимодействии адсорбированных молекул циклогексадиена с диссоциативно адсорбированными молекулами кислорода. На основе этого механизма можно написать следующие уравнения для скорости образования $\mathrm{CO}_{2}$ и $\mathrm{C}_{6} \mathrm{H}_{6}$ :

$$
\begin{aligned}
& r_{5}=\frac{k_{5} K_{4} P_{4} K_{6} P_{2}}{\left(1+K_{1} P_{1}+\sqrt{K_{2} P_{2}}+K_{3} P_{3}+K_{4} P_{4}+K_{5} P_{5}+K_{6} P_{2}\right)^{2}} \\
& r_{6}=\frac{k_{3} K_{4} P_{4} \sqrt{K_{2} P_{2}}}{\left(1+K_{1} P_{1}+\sqrt{K_{2} P_{2}}+K_{3} P_{3}+K_{4} P_{4}+K_{5} P_{5}+K_{6} P_{2}\right)^{2}}
\end{aligned}
$$

Согласно кинетической схеме (10) уравнения суммарной скорости образования циклогексадиена-1,3 и бензола имеют вид:

$$
\begin{gathered}
r_{C_{6} H_{8}}=r_{2}-r_{5}-r_{6} \\
r_{C_{6} H_{6}}=r_{6}
\end{gathered}
$$

С учётом образования двуокиси углерода при взаимодействии адсорбированных молекул циклогексана и кислорода по кинетическому уравнению

$$
r_{7}=\frac{k_{4} K_{1} P_{1} K_{6} P_{2}}{\left(1+K_{1} P_{1}+\sqrt{K_{2} P_{2}}+K_{3} P_{3}+K_{4} P_{4}+K_{5} P_{5}+K_{6} P_{2}\right)^{2}}
$$

и согласно кинетической схеме (10) уравнения суммарной скорости образования двуокиси углерода можно представить следующим уравнением

$$
r_{\mathrm{CO}_{2}}=r_{7}+r_{3}+r_{5}
$$

Уравнение суммарной скорости образования циклогексанола имеет вид

$$
r_{\mathrm{C}_{6} \mathrm{H}_{11} \mathrm{OH}}=r_{4}
$$

Уравнения (15), (18), (19), (21) и (22) составляют кинетическую модель рассматриваемого процесса.

Таблица 8

\section{Численные значения констант кинетической модели реакции окислительного дегидрирования циклогексана}

\begin{tabular}{|c|c|c|c|}
\hline \multicolumn{2}{|c|}{$\ln k_{i}^{0}\left(\ln K_{i}^{0}\right)$} & \multicolumn{2}{c|}{$E_{i}\left(Q_{i}\right)$, ккал/моль } \\
\hline $\ln k_{1}^{0}$ & 34.18 & $E_{1}$ & 25.25 \\
\hline $\ln k_{2}^{0}$ & 51.77 & $E_{2}$ & 31.94 \\
\hline $\ln k_{3}^{0}$ & 32.24 & $E_{3}$ & 10.01 \\
\hline $\ln k_{4}^{0}$ & 20.86 & $E_{4}$ & 35.15 \\
\hline $\ln k_{5}^{0}$ & 41.52 & $E_{5}$ & 21.55 \\
\hline $\ln k_{6}^{0}$ & 23.17 & $E_{6}$ & 17.82 \\
\hline $\ln k_{7}^{0}$ & 10.51 & $E_{7}$ & 39.79 \\
\hline $\ln K_{1}^{0}$ & 23.16 & $Q_{1}$ & 2.49 \\
\hline $\ln K_{2}^{0}$ & 1.02 & $Q_{2}$ & 11.00 \\
\hline $\ln K_{3}^{0}$ & 8.75 & $Q_{3}$ & 8.57 \\
\hline
\end{tabular}




\begin{tabular}{|c|c|c|c|}
\hline $\ln K_{4}^{0}$ & 6.84 & $Q_{4}$ & 11.00 \\
\hline $\ln K_{5}^{0}$ & 25.48 & $Q_{5}$ & 3.19 \\
\hline $\ln K_{6}^{0}$ & 3.027 & $Q_{6}$ & 2.49 \\
\hline
\end{tabular}

Разработанная кинетическая модель реакции подвергнута статистическому анализу на основании кинетических данных. Расчёт предэкспоненциальных множителей реакционных констант $\ln k_{i}^{0}\left(\ln K_{i}^{0}\right)$, значения энергий активации $\left(E_{i}^{0}\right)$ и теплоты адсорбции $\left(Q_{i}^{0}\right)$ проведен методами «скользящего допуска» и Пауэля с использованием программной системы «Поиск». Численные значения констант кинетической модели представлены в таблице. Расчёты показали, что относительная погрешность экспериментальных и расчётных данных не превышала 10-12 \%.

В настоящее время ведутся аналогичные исследования для реакций окислительного дегидрирования метициклогексана, циклопентана и метилцикпентана в соответствующие диены на модифицированных цеолитных катализаторах.

Окислительное димеризация метана на на цеолитных катализаторах модифицированных катионами металлов

Процесс получения этана, этилена и ацетилена каталитической окислительной димеризацией метана (ОДМ) является одним из перспективных способов синтеза продуктов нефтехимической промышленности на основе альтернативного источника углеводородного сырья - природного газа.

Каталитическому окислительному превращению метана посвящено множество работ [88-97]. Предложены разные нанесенные катализаторы для указанного процесса с целью получения этана и этилена. Характерными особенностями процесса ОДМ, осуществляемого на всех известных катализаторах, являются высокие температуры, сильная экзотермичность протекающих в системе реакций и в связи с этим взрывоопасность смеси $\mathrm{CH}_{4}+\mathrm{O}_{2}$, что препятствует промышленной реализации процесса. Активность и селективность катализаторов сравнительно низкие. Кроме того, на большинстве изученных в литературе катализаторах кинетика окислительной димеризации метана не изучалась. Исключения составляют системы $\mathrm{Bi}_{2} \mathrm{O}_{3}-9 \% \mathrm{~K}_{2} \mathrm{CO}_{3} / \mathrm{Al}_{2} \mathrm{O}_{3}$ и $34 \% \mathrm{PbO} / \mathrm{Al}_{2} \mathrm{O}_{3}$ [98]. Однако в обоих случаях для кинетического описания применяли формальные степенные уравнения.

При этом целевым продуктом являлся только этилен, получаемый при проведении процесса в одном реакционном узле. Становится ясным, что в настоящее время процессы химической переработки метана в ценные продукты - этилен и ацетилен находятся в стадии исследования.

При рассмотрении результатов окислительного превращения метана на металлцеолитных катализаторах с получением этилена и ацетилена [99-101] установлено, что лучшими для осуществления этого процесса являются именно цеолиты.

В связи с этим нами проведены исследования активности катализаторов приготовленных на основе природного цеолита клиноптилолита, модифицированного ионами металлов $\mathrm{Ca}, \mathrm{Mg}, \mathrm{Mn}, \mathrm{Li}$ в различных комбинациях в реакции окислительной димеризацией метана [102]. Наиболее активным для реакции окислительной димеризации метана оказался цеолитный катализатор $\mathrm{LiMgCa}$ клиноптилолит с $\mathrm{SiO}_{2} / \mathrm{Al}_{2} \mathrm{O}_{3}=10.8$, содержащий (в масс.\%): $\mathrm{Li}^{+}-7.0 ; \mathrm{Mg}^{2+}-8.0 ; \mathrm{Ca}^{2+}-8.0$.

С целью выявления вероятной стадийной схемы механизма реакции нами изучены кинетические закономерности протекания реакции. Реакцию проводили в двухступенчатом реакторе в изотермическом режиме со ступенчатой подачей кислорода. Условия проведения реакции и результаты экспериментального исследования представлены в табл. 9. 
Результаты экспериментального исследования реакции окислительной

Таблица 9 димеризации метана в двухступенчатом реакторе

\begin{tabular}{|c|c|c|c|c|c|c|c|c|c|c|c|}
\hline \multirow[b]{2}{*}{$\begin{array}{l}T^{I}, \\
{ }^{\circ} \mathrm{C}\end{array}$} & \multirow[b]{2}{*}{$\begin{array}{l}T^{I I}, \\
{ }^{\circ} \mathrm{C}\end{array}$} & \multirow{2}{*}{$\begin{array}{c}n_{\mathrm{CH}_{4}}^{0}, \\
\text { моль/ } \\
\text { ч }\end{array}$} & \multirow{2}{*}{$\begin{array}{c}n_{\mathrm{O}_{2}}^{\mathrm{I}}, \\
\text { моль } / \\
\text { ч }\end{array}$} & \multirow{2}{*}{$\begin{array}{c}n_{\mathrm{O}_{2}}^{\mathrm{II}}, \\
\text { моль/ч }\end{array}$} & \multirow{2}{*}{$\begin{array}{c}\text { Объёмная } \\
\text { скорость, } \\
\text { ч }^{-1}\end{array}$} & \multirow{2}{*}{$\begin{array}{c}\text { Степень } \\
\text { превращен } \\
\text { ия } \\
\text { метана,\% }\end{array}$} & \multicolumn{5}{|c|}{ Выход (\%) } \\
\hline & & & & & & & $\mathrm{C}_{2} \mathrm{H}_{2}$ & $\mathrm{C}_{2} \mathrm{H}_{4}$ & $\mathrm{CO}$ & $\mathrm{CO}_{2}$ & $\mathrm{C}_{2} \mathrm{H}_{6}$ \\
\hline 800 & 700 & 0.267 & 0.196 & 0.139 & 12600 & 73.0 & 22.8 & 14.8 & 3.1 & 44.7 & $\mathrm{O}$ \\
\hline 700 & 650 & 0.312 & 0.294 & 0.215 & 16000 & 70.0 & 19.2 & 11.9 & 3.4 & 35.5 & 0.07 \\
\hline 750 & 700 & 0.312 & 0.294 & 0.134 & 16000 & 70.9 & 20.4 & 9.7 & 3.1 & 37.7 & 0.163 \\
\hline 800 & 700 & 0.357 & 0.294 & 0.161 & 16000 & 81.9 & 23.1 & 11.4 & 2.2 & 45.2 & 0.08 \\
\hline 800 & 700 & 0.312 & 0.294 & 0.161 & 17000 & 78.1 & 20.8 & 7.9 & 2.7 & 46.7 & 0.07 \\
\hline 800 & 700 & 0.312 & 0.294 & 0.161 & 18000 & 74.4 & 20.1 & 7.8 & 3.9 & 42.6 & 0.07 \\
\hline 800 & 700 & 0.357 & 0.294 & 0.161 & 18000 & 73.3 & 21.4 & 11.3 & 2.8 & 37.8 & 0.07 \\
\hline 700 & 650 & 0.402 & 0.294 & 0.215 & 19000 & 68.2 & 17.1 & 15.2 & 3.2 & 32.8 & $\mathrm{O}$ \\
\hline 750 & 700 & 0.402 & 0.294 & 0.215 & 19000 & 73.0 & 18.4 & 15.0 & 3.0 & 36.4 & 0.07 \\
\hline 850 & 700 & 0.402 & 0.196 & 0.214 & 19000 & 76.8 & 20.1 & 8.7 & 4.1 & 43.9 & 0 \\
\hline 800 & 700 & 0.535 & 0.343 & 0.331 & 22600 & 72.7 & 25.9 & 17.5 & 2.5 & 26.8 & $\mathrm{O}$ \\
\hline 800 & 700 & 0.535 & 0.343 & 0.331 & 25200 & 65.0 & 23.7 & 16.0 & 2.6 & 22.7 & 0.13 \\
\hline
\end{tabular}

Как следует из табличных данных контактный газ на выходе из второго реактора содержит $\mathrm{C}_{2} \mathrm{H}_{2}, \mathrm{C}_{2} \mathrm{H}_{4}, \mathrm{C}_{2} \mathrm{H}_{6}, \mathrm{CO}$, и $\mathrm{CO}_{2}$. С целью выявления кинетической схемы протекания реации процесса окислительной димеризацией метана нами была проведена серия опытов в одноступенчатом реакторе с разными свободными объемами после слоя катализатора. Условия проведения опытов и результаты исследования представлены в табл. 10.

Таблица 10

Результаты экспериментального исследования реакции окислительной
димеризации метана в одноступенчатом реакторе

\begin{tabular}{|c|c|c|c|c|c|c|}
\hline \multirow{3}{*}{$T,{ }^{\circ} \mathrm{C}$} & \multirow{3}{*}{$\begin{array}{c}n_{\mathrm{CH}_{4}}^{0}, \\
\text { моЛЬ/ч }\end{array}$} & \multirow{3}{*}{$\begin{array}{c}n_{\mathrm{O}_{2}}^{0}, \\
\text { моль/ч }\end{array}$} & \multicolumn{4}{|c|}{ Выход, \% } \\
\hline & & & \multicolumn{2}{|c|}{$V_{\text {св.об. }}=45 \mathrm{~cm}^{3}, V$ кат $=0,5 \mathrm{~cm}^{3}$} & \multirow{2}{*}{$\frac{V_{\text {св.об. }}=25 \mathrm{~cm}^{3},}{\mathrm{C}_{2} \mathrm{H}_{6}}$} & \multirow{2}{*}{$\begin{array}{c}V \text { кат }=0,5 \text { cM }^{3} \\
\mathrm{C}_{2} \mathrm{H}_{4}\end{array}$} \\
\hline & & & $\mathrm{C}_{2} \mathrm{H}_{6}$ & $\mathrm{C}_{2} \mathrm{H}_{4}$ & & \\
\hline 800 & 0.312 & 0.267 & $15 \cdot 4$ & 17.1 & 26.2 & $5 \cdot 3$ \\
\hline 800 & 0.402 & 0.2671 & 12.49 & 14.9 & 22.69 & 4.7 \\
\hline 800 & 0.402 & 0.267 & 12.49 & 14.9 & 22.69 & 4.7 \\
\hline 800 & 0.402 & 0.244 & 12.26 & 14.1 & 22.16 & 4.2 \\
\hline 800 & 0.402 & 0.267 & 12.49 & 14.9 & 22.69 & 4.7 \\
\hline 800 & 0.267 & 0.178 & 12.49 & 14.9 & 22.69 & 4.7 \\
\hline 800 & 0.535 & 0.443 & 14.69 & 16.8 & 26.59 & 4.9 \\
\hline 800 & 0.535 & 0.343 & 12.78 & 14.6 & 22.88 & 4.5 \\
\hline 800 & 0.535 & 0.343 & 12.78 & 14.6 & 22.88 & 4.5 \\
\hline 800 & 0.535 & 0.312 & 11.67 & 13.8 & 21.77 & 3.7 \\
\hline
\end{tabular}

Из таблицы видим, что с уменьшением свободного объема реактора после слоя катализатора выход этилена уменьшается, а этана увеличивается при одинаковом неизменном объеме катализатора. Это объясняется уменьшением времени контакта процесса пиролиза этана в этилен в меньшем объеме реактора.

Из этого можно сделать вывод, что реакция димеризации метана в этан протекает на поверхности катализатора - здесь происходит взаимодействие диссоциативно адсорбированных молекул кислорода с молекулами метана с образованием кислородуглеводородного поверхностно-комплексного соединения $\mathrm{ZOCH}_{3}$, которое, взаимодействуя с молекулами метана, ведет к образованию этана. Этилен же образуется в свободном объеме реактора в процессе пиролиза поступившего сюда из слоя катализатора этана без участия катализатора и кислорода. Как показал состав контактного газа $\left(\mathrm{C}_{2} \mathrm{H}_{6}, \mathrm{C}_{2} \mathrm{H}_{4}, \mathrm{CH}_{4}, \mathrm{CO}, \mathrm{CO}_{2}\right.$, 
$\mathrm{H}_{2} \mathrm{O}, \mathrm{H}_{2}, \mathrm{O}_{2}$ ), ацетилен в рассмотренных случаях не образуется. Поэтому для возможности получения второго целевого продукта-ацетилена нами предложен способ совмещения реакций окислительной димеризации метана в этан, дегидрирования этана в этилен и окислительного дегидрирования этилена в ацетилен. Для этого к одному реактору последовательно соединили второй с таким же объемом катализатора.

Таким образом, на основе проведенных эксперментальных исследований кинетическую схему протеканий реакций процесса окислительной димеризацией метана в двухступенчатом реакторе со ступенчатой подачей кислорода можно представить в виде:

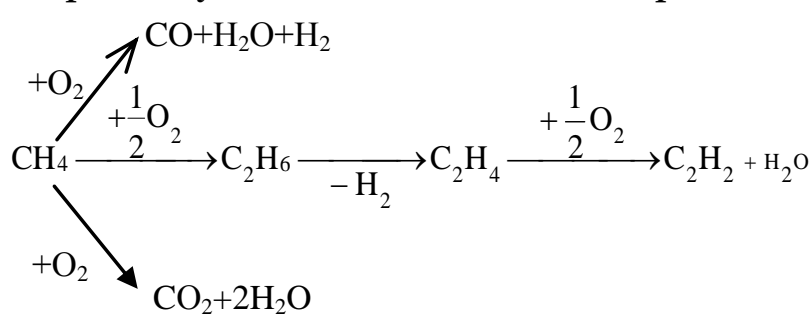

Вероятный стадийный механизм образования этана можно представит в виде:

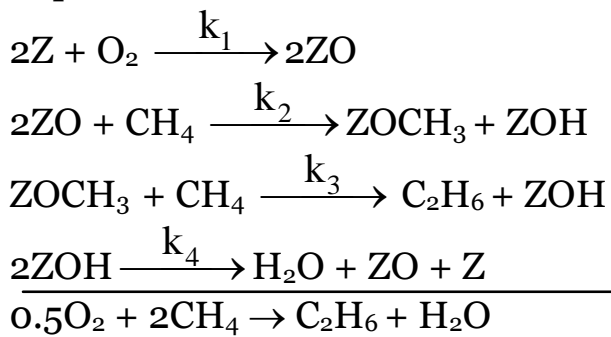

В условиях стационарности $\mathrm{r}_{1}=\mathrm{r}_{2}=\mathrm{r}_{3}=\mathrm{r}_{4}$ и постоянства общего числа поверхностных участков $\sum \theta_{\mathrm{i}}=1$ соответствующее этому механизму уравнение скорости образования этана:

$$
r_{\mathrm{C}_{2} \mathrm{H}_{6}}=\frac{k_{3}^{2} P_{\mathrm{CH}_{4}}}{4 k_{2}}\left\{-\left(\sqrt{\frac{k_{2} P_{\mathrm{CH}_{4}}}{k_{1} P_{\mathrm{O}_{2}}}}+\sqrt{\frac{k_{2} P_{\mathrm{CH}_{4}}}{k_{4}}}+1\right)+\sqrt{\left(\sqrt{\frac{k_{2} P_{\mathrm{CH}_{4}}}{k_{1} P_{\mathrm{O}_{2}}}}+\sqrt{\frac{k_{2} P_{\mathrm{CH}_{4}}}{k_{4}}}+1\right)^{2}+4 \frac{k_{2}}{k_{3}}}\right\}^{2}
$$

Реакция дегидрирования этана в этилен происходит в свободных объемах VI и VII по радикально-цепному механизму [103].

$$
\begin{aligned}
& \mathrm{C}_{2} \mathrm{H}_{6} \stackrel{k_{5}}{\longrightarrow} 2 \mathrm{CH}_{3} \\
& \mathrm{CH}_{3}+\mathrm{C}_{2} \mathrm{H}_{6} \stackrel{k_{6}}{\longrightarrow} \mathrm{CH}_{4}+\mathrm{C}_{2} \mathrm{H}_{5} \\
& \mathrm{C}_{2} \mathrm{H}_{5} \stackrel{k_{7}}{\longrightarrow} \mathrm{C}_{2} \mathrm{H}_{4}+\mathrm{H}_{2} \\
& \mathrm{H}+\mathrm{C}_{2} \mathrm{H}_{6} \stackrel{k_{8}}{\longrightarrow} \mathrm{C}_{2} \mathrm{H}_{5}+\mathrm{H}_{2} \\
& 2 \mathrm{C}_{2} \mathrm{H}_{5} \stackrel{k_{9}}{\longrightarrow} \mathrm{C}_{2} \mathrm{H}_{4}+\mathrm{C}_{2} \mathrm{H}_{6} \\
& 2 \mathrm{C}_{2} \mathrm{H}_{5} \stackrel{k_{10}}{\longrightarrow} \mathrm{C}_{4} \mathrm{H}_{10} \\
& \stackrel{2 \mathrm{CH}_{3} \stackrel{k_{11}}{\longrightarrow} \mathrm{C}_{2} \mathrm{H}_{6}}{\mathrm{C}_{2} \mathrm{H}_{6} \longrightarrow \mathrm{C}_{2} \mathrm{H}_{4}+\mathrm{H}_{2}}
\end{aligned}
$$

Уравнение скорости образования этилена, соответствующее этому механизму:

$$
r_{\mathrm{C}_{2} \mathrm{H}_{4}}=3 k_{6} P_{\mathrm{C}_{2} \mathrm{H}_{6}}\left(1-\frac{0.33}{1+\frac{K_{8}}{k_{9}}}\right)+\frac{k_{5}\left(\frac{k_{7}}{k_{9}}\right)^{1 / 2}}{\left(1+\frac{k_{8}}{k_{9}}\right)^{1 / 2}} P_{\mathrm{C}_{2} \mathrm{H}_{6}}^{1 / 2}
$$

Диоксид углерода $\mathrm{CO}_{2}$ обнаружен в составе контактного газа на выходе из I и II реакторов, что свидетельствует об образовании его на поверхности обоих катализаторов. 
Реакция протекает при взаимодействии слабо адсорбированных молекул кислорода и метана.

Механизм этой реакции имеет вид:

$\mathrm{O}_{2}+\mathrm{Z} \stackrel{K_{1}^{*}}{\longrightarrow} \mathrm{O}_{2} \mathrm{Z}$

$\mathrm{CH}_{4}+\mathrm{Z} \stackrel{K_{2}^{*}}{\longrightarrow} \mathrm{CH}_{4} \mathrm{Z}$

$\mathrm{ZCH}_{4}+2 \mathrm{ZO}_{2} \stackrel{k}{\stackrel{k}{\longrightarrow}} 2 \mathrm{CO}_{2}+2 \mathrm{H}_{2} \mathrm{O}+3 \mathrm{Z}$

Уравнение скорости образования $\mathrm{CO}_{2}$ :

$$
\mathrm{r}_{\mathrm{CO}_{2}}=\frac{2 k_{12} K_{1}^{*} P_{\mathrm{O}_{2}} K_{2}^{*} P_{\mathrm{CH}_{4}}}{\left(1+K_{1}^{*} \mathrm{P}_{2}+K_{2}^{*} \mathrm{P}_{\mathrm{CH}_{4}}\right)^{2}}
$$

Оксид углерода СО образуется на выходе из I и II реакторов в незначительных количествах. Реакция протекает при взаимодействии диссоциативно адсорбированных молекул кислорода с молекулами метана:

$$
\begin{aligned}
& 2 \mathrm{Z}+\mathrm{O}_{2} \stackrel{K_{1}}{\longrightarrow} 2 \mathrm{ZO} \\
& \frac{2 \mathrm{ZO}+\mathrm{CH}_{4} \stackrel{k_{13}}{\longrightarrow} \mathrm{CO}+2 \mathrm{Z}+\mathrm{H}_{2}+\mathrm{H}_{2} \mathrm{O}}{\mathrm{O}_{2}+2 \mathrm{CH}_{4} \rightarrow 2 \mathrm{CO}+3 \mathrm{H}_{2}+\mathrm{H}_{2} \mathrm{O}}
\end{aligned}
$$

Уравнение скорости образования СО:

$$
r_{\mathrm{CO}}=k_{13} P_{\mathrm{CH}_{4}}\left(\frac{1}{1+\sqrt{\frac{k_{13} P_{\mathrm{CH}_{4}}}{K_{1} P_{\mathrm{O}_{2}}}}}\right)^{2}
$$

Реакция окислительного дегидрирования этилена в ацетилен происходит при взаимодействии диссоциативно адсорбированных молекул кислорода с молекулами этилена, образуя кислород-углеводородное поверхностно-комплексное соединение $Z \mathrm{OC}_{2} \mathrm{H}_{4}$, которое разлагается на молекулы ацетилена и воды.

Механизм этой реакции имеет вид:

$$
\begin{aligned}
& 2 \mathrm{Z}+\mathrm{O}_{2} \stackrel{k_{1}}{\longrightarrow} 2 \mathrm{ZO} \\
& \mathrm{ZO}+\mathrm{C}_{2} \mathrm{H}_{4} \stackrel{k_{14}}{\longrightarrow} \mathrm{ZOC}_{2} \mathrm{H}_{4} \\
& \mathrm{ZOC}_{2} \mathrm{H}_{4} \stackrel{k_{15}}{\longrightarrow} \mathrm{C}_{2} \mathrm{H}_{2}+\mathrm{H}_{2} \mathrm{O}+\mathrm{Z} \\
& \mathrm{O.5} \mathrm{O}_{2}+\mathrm{C}_{2} \mathrm{H}_{4} \rightarrow \mathrm{C}_{2} \mathrm{H}_{2}+\mathrm{H}_{2} \mathrm{O}
\end{aligned}
$$

Уравнение скорости образования ацетилена, соответствующее этому механизму в условиях сационарности имеет вид:

$$
r_{\mathrm{C}_{2} \mathrm{H}_{2}}=k_{1} P_{\mathrm{O}_{4}}\left[\frac{-1+\sqrt{1+4\left(\frac{k_{1} P_{\mathrm{O}_{2}}}{k_{14} P_{\mathrm{C}_{2} \mathrm{H}_{4}}}+\frac{K_{1} P_{\mathrm{O}_{2}}}{k_{15}}\right)}}{2\left(\frac{k_{1} P_{\mathrm{O}_{2}}}{k_{14} P_{\mathrm{C}_{2} \mathrm{H}_{4}}}+\frac{k_{1} P_{\mathrm{O}_{2}}}{k_{15}}\right)}\right]^{2}
$$

Уравнения (23-27) составляют кинетическую модель процесса.

Параметры кинетической модели определяли на основе экспериментальных данных приведенных в табл. 9 с использованием целевой функциии: 
где $\mathrm{x}$-кинетический параметр рассматриваемой модели; $\mathrm{A}_{\text {эксп }}, \mathrm{A}_{\text {расч }}$ экспериментальные и расчетные значения выходов продуктов реакции; $\mathrm{N}$ - число компонентов.

Численные значения параметров кинетической модели представлены в таблице 3.

Разработанная кинетическая модель реакции ОДМ в этилен и ацетилен адекватно описывает экспериментальные данные (относительная погрешность экспериментальных и расчетных данных не превышает $10 \%)$.

Таблиц̧а 11

Численные значения констант кинетической модели реакции ОДМ

\begin{tabular}{|c|c|c|c|}
\hline \multicolumn{2}{|c|}{ Предэкспоненциальный множитель } & \multicolumn{2}{|c|}{ Энергия активации, ккал/моль } \\
\hline $\ln K_{1}^{0}$ & 16.79 & $E_{1}$ & 6.62 \\
\hline $\ln K_{2}^{0}$ & 22.24 & $E_{2}$ & 30.34 \\
\hline $\ln K_{3}^{0}$ & 43.08 & $E_{3}$ & 26.16 \\
\hline $\ln K_{4}^{0}$ & 3.48 & $E_{4}$ & 16.28 \\
\hline $\ln K_{6}$ & 12.08 & $E_{5}$ & 14.49 \\
\hline $\ln K_{5}$ & -16.43 & $E_{6}$ & 4.47 \\
\hline $\ln K_{7}^{0}$ & 38.93 & $E_{7}$ & 61.96 \\
\hline $\ln K_{8}^{0}$ & -9.25 & $E_{8}$ & 0.475 \\
\hline $\ln K_{9}^{0}$ & 1.77 & $E_{9}$ & 0.59 \\
\hline $\ln K_{1}^{*}$ & 14.163 & $Q_{1}^{*}$ & 3.676 \\
\hline $\ln K_{2}^{*}$ & 15.033 & $Q_{2}^{*}$ & 3.023 \\
\hline $\ln K_{12}^{0}$ & 2.997 & $E_{12}$ & 11.581 \\
\hline $\ln K_{13}$ & 20.681 & $E_{13}$ & 5.807 \\
\hline $\ln K_{14}$ & 1.748 & $E_{14}$ & 4.834 \\
\hline $\ln K_{15}$ & 20.68 & $E_{15}$ & 5.807 \\
\hline
\end{tabular}

Таким образом, кинетическим методом доказаны предложенные механизмы образования продуктов процесса окислительной димеризации метана с участием металлцеолитного катализатора.

\section{Заключение}

Таким образом приготовление металлцеолитных катализаторов модифицированием цеолитов методом ионного обмена с катионами металлов с известными каталитическими свойствами позволяет синтезировать высокодисперсные каталитические системы для разных классов реакций. Такие катализаторы значительно снижают температуру реакции и повышают селективность процесса по целевому продукту.

Этим методом нами синтезирован эффективный металлцеолитный катализатор для реакций газофазного окисления низших олефиновых углеводородов в карбонильные соединения. Изучена кинетика и механизм реакций. Представляет интерес синтез металлцеолитных катализаторов для парциального окисления алифатических спиртов предложенным методом. Нами синтезирован около 16 эффективных металлцеолитных 
катализаторов для реакций парциального окисления алифатических спиртов в соответствующие альдегиды, кетоны, карбоновые кислоты и сложные эфиры.

Представляет интерес также предложенные общие принципы конструирования металлцеолитных катализаторов для реакций селективного парциального окисления алифатических спиртов, стадийный механизм окисления спиртов на металлцеолитных катализаторах и общая кинетическая модель процесса составленная на основе стадийного механизма.

Кроме того в работе приведены результаты экспериментального исследования реакций; селективного окислительного дегидрирования циклогексана в циклогексадиен-1,3 и окислительной димеризации метана в этилен и ацетилен на синтезированных нами эффективных металлцеолитных катализаторах.

\section{Примечания:}

1. Миначев Х.М., Исаков Я.И. Металлсодержащие цеолиты в катализе. М.: «Наука», 1976. $111 \mathrm{c}$.

2. Ландау М.В., Кругликов В.Я., Коновальчиков О.Д. // Химия и технология топлив и масел. 4, 10 (1976)

3. Patent US 4237073 (1980)

4. Жданов С.П., Хвощев С.С., Самулевич Н.Н. Синтетические цеолиты. М.: «Химия», 1981. 264 c.

5. Касамански В.П. Дис. канд. хим. наук. ИНФХ АН Азерб. ССР, Баку, 1982.

6. Касум-заде А.Ю. Дис. канд. хим. наук. ИТПХТ АН Азерб. ССР, Баку, 1992.

7. Мурадов М.Х. Дис. канд. хим. наук. ИТПХТ им. М.Ф.Нагиева АН Азербайджана, Баку, 1999.

8. Гусейнов К.А. Дис. канд. хим. наук. ИХП им. М.Ф.Нагиева Национальной АН Азербайджана, Баку, 2009.

9. Фатуллаева С.С. Дис. канд. хим. наук. ИХП им. М.Ф.Нагиева Национальной АН Азербайджана, Баку, 2004.

10. Алиев А.М., Шабанова 3.А., Наджаф-Кулиев У.М., Меджидова С.М., Али-заде Г.А. //Нефтепереработка и нефтехимия. 5, 27 (2013)

11. Азизов А.О. Дис. канд. хим. наук. ИТПХТ АН Азерб. ССР, Баку, 1991, 124 с.

12.Aliyev A.M., Aliyev F.V., Matiyev K.I., M. Al-Dosari. In the proceedings of the 15th International Congress on Catalysis. Munich, Germany, 2012. Vol.1. P.1508

13.Шахтахтинский Т.Н., Алиев А.М., Кулиев А.Р., Бэнни Харри Ф., Касаманский В.П., Пересада И.М. //Азербайджанский химический журнал. 2, 41 (1979)

14. Алиев А.М., Кулиев А.Р., Касаманский В.П., Микаилов Р.З. ХІІ Менделеевский съезд по общей и прикладной химии. Рефераты докладов и сообщений. М.: Наука, 1981. С. 75.

15. Shakhtakhtinsky T.N., Aliyev A.M., Kuliyev A.R., Kasamansky V.P. In the proceedings of the 6 th American-Soviet Symposium on Chemical Catalysts. USA. New Jersey, Cherry Hill. June, 1979. P. 143 .

16. Алиев А.М., Касаманский В.П., Шахтахтинский Т.Н., Кулиев А.Р., Микаилов Р.З., Исмайлов Э.Г. Тезисы докладов II Всесоюзной конф. по применению цеолитов в катализе. Москва. 1981. С. 199.

17.Шахтахтинский Т.Н., Алиев А.М., Кулиев А.Р., Бэнни Харри Ф., Касаманский В.П., Микаилов Р.3. Азербайджанский химический журнал. 2, 57 (1979).

18. Aliyev A.M., Mikailov R.Z., Azizov A.O., Yariyev V.M., Yunisova F.A., Efendiev A.A. In the Proceedings of Symp. Industrial Applications of Zeolites. Brugge, Belgium. 2000. P. 251.

19. Алиев А.М., Микаилов Р.З., Гасанов Э.А., Агаева Р.Ю. Азербайджанский химический журнал. 1, 10 (2004)

20. Шахтахтинский Т.Н., Алиев А.М., Кулиев А.Р., Касаманский В.П., Микаилов Р.З.. Тезисы докладов V Международного симпозиума по гетерогенному катализу. Варна. 1983. T. 1. C. 147.

21. Алиев А.М., Абдуллаев Р.Х., Мамедов А.А., Микаилов Р.З., Агаева Р.Ю. Азербайджанский химический журнал. 2, 7 (2000)

22. А.М.Алиев, Р.З. Микаилов, Э.А. Гасанов, Р.Ю. Агаева. Азербайджанский химический журнал. 3,118 (2006). 
23. Шахтахтинский Т.Н., Алиев А.М., Кулиев А.Р., Касаманский В.П., Микаилов Р.З., Ибрагимов З.И. Кинетика и катализ. Т. 27. 4, 966 (1986)

24. Микаилов Р.З. Дис.канд. хим. наук. ИТПХТ АН Азерб. ССР, Баку. 1984.

25. Брайловский С.М., Темкин О.Н., Трофимова И.В. Проблемы кинетики и катализа. М.: Наука, 1985. Т. 19. С. 146.

26. Nishmure Psutomu // J. Catal. 48, 413 (1977) (1986)

27. Яковенко 3.И., Колганова С.А., Курина М.Н. Журнал физической химии. 59, 253 (1998)

28. Klissurski Dimiter G., Abadzhjieva Nevena T., Triffiro F. Bulg. Chem. Commun. 30, 448

29. Keleypette Dono, Zhu Zhi-hua, Xu Pei-Zuo // J E China Univ., Sci. and Technol. 26, 134 (2000)

30. Mao C.F., Vannice M.A. // J. Catal. 154, 230 (1995)

31.Naoki Narishige, Miki Niwa // Catalysis Letter. 71, 63 (2001)

32. Лазарева Т.В., Осипова Н.А., Курина Л.Н. Изв. ВУЗов. Химия и хим. Технология. 33, 49 (1990) 1990.

33. Mahipal Reddy B., Narsimha R., Sivaraj Ch., Kanta Rao P. Appl. Catal. 55, 41 (1989)

34. Wong G.S., Kragten D.D., Vohs J.M. // J. Phys. Chem. B. 105, 1366 (2001)

35. Soares A.P.V., Portela Farinha, A. Kiennemann, L.Hilaire, J.M.Millet. Applied Catalysis. A: General. 206, 221 (2001)

36. Koltunov K. Yu., Sobolev V. I. Catalysis in Industry., 4, 247 (2012) 1987).

37. Курина Л.Н., Осипова Н.А., Давыдов А.А. // Деп. ВИНИТИ. №5082-В87 (Москва,

38. Патент SU № 1817768 АЗ (Госпатент ССCP) (1993)

39. Патент и 20030204 Аз.Р. (2003)

40. А.c. № 1549945 СССР. Зарегистрировано в Гос. реестре изобретений СССР 15 ноября 1989 г. // Опубликовано 15.03.90.

41.Алиев А.М. Тезисы докладов III Международной конф. "Тонкий органический синтез и катализ", посвященная 85-летнему юбилею АГНА. Баку. 2005. С. 25

42. Алиев А.М., Кулиев А.Р., Гусейнов К.А., Меджидова С.М., Ализаде Г.А., Агаева Р.Ю. //Азербайджанский химический журнал. 2, 121 (2006)

43. А.c. № 1372874 СССР. Зарегистрировано в Гос. реестре изобретений СССР 8 октября 1987 г. ДСП.

44. Aliyev A.M., Shakhtakhtinsky T.N., Ali A.Ghorbanpour, Alikhanova Z.A., Guseynov K.A., Agayeva R..Yu., Sarijanov A.A., Matiyev K.I. In the proceedings of the $6^{\text {th }}$ World Congress on Oxidation Catalysis. Towards an Integrated Approarch in Innovation and Development. Lille, France. 2009. Poster Session A. 1B-92. P. 110

45. Алиев А.М., Меджидова С.М., Шахтахтинский Т.Н., Гусейнов К.А. Изв. Вузов Химия и химическая технология. 53, 95 (2010)

46. Алиев А.М., Меджидова С.М., Гусейнов К.А., Ализаде Г.А., Агаева Р.Ю., Касум-заде А.Ю., Мамедова У.А. Труды ХІХ Менделеевского съезда по общей и прикладной химии. Волгоград, Россия. 2011. С.466.

47. Гусейнов К.А. Хим. Проблемы, 3, 582 (2007)

48. Алиев А.М., Кесаманская С.В., Бабаева А.Р., Сеидов А.Г., Кулиев А.P. IV Всесоюзная конф. "Применение цеолитов в катализе". Москва, 1989. С. 189.

49. Шахтахтинский Т.Н., Алиев А.М., Кулиев А.Р., Меджидова С.М., Мурадов М.Х. Докл. АН России. 343, 496(1995)

50. Меджидова С.М. Хим. проблемы. 4, 695 (2010)

51.Aliyev A.M., Medjidova S.M, Kuliyev A.R., Shakhtakhtinsky T.N., Fatullayeva S.S., Tagiev D.B., Sarijanov A.A., Agayeva R.Y. Abstracts of the 1st Aegean Physical Chemistry days. 2002. Bornova-Izmir. Türkiye. P.307

52. Aliyev A.M., Tagiev D.B., Fatullaeva S.S., Kuliev A.R., Mejidova S.M. Abstracts of the 17 th International conf. of Chemical Reactors "Chemreactor-17". 2006. Athens-Crete, Greece. PP. 121. P. 701-704. 
53. $\quad$ Aliyev A.M., Medzhidova S.M., Shakhtakhtinski T.N., Kuliev A.R., Agayeva R.Yu, Kasumzade A.Yu., Fatullaeva S.S. In the Proceedings of Symp. Industrial Applications of Zeolites. Brugge, Belgium, 2000. P. 245.

54. A.M.Aliyev, D.B.Tagiev, S.M.Medzhidova, S.S Fatullaeva., A.R Kuliyev., T.N. Shakhtakhtinsky, G.A.Alizade, K.I. Matiyev. In the Proceedings of the $13^{\text {th }}$ International Zeolite Conf. Zeolites and Mezoporous Materials of the Down of the $21^{\text {st }}$ Sentury”. 2001. France, Montpellier. 27-P-08. P. 365.

55. С.М.Меджидова. Азербайджанский химический журнал. 4, 138 (2010)

56. A.M. Aliyev, D.B.Tagiev, S.M.Mejidova, A.R.Kuliyev, S.S.Fatullayeva, G.Alizade, R.Y.Agayeva. Abstracts of the 39 th TOPAC International Congress and 86 Conference of the Zeolite. Canadian Society for Chemistry. 2003. Ottawa-Ontario-Canada. IN-5 Poster

57. К.И.Матиев, А.М.Алиев, С.М.Меджидова. Азербайджанское нефтяное хозяйство. l, $40(1998)$

58. Алиев А.М., Кулиев А.Р., Меджидова С.М., Матиев К.И., Касум-заде А.Ю. Тезисы докладов II Бакинской Международной нефтяной конф., посвященная памяти акад. Ю.Г.Мамедалиева. Баку. 1996. С. 164.

59. Матиев К.И., Алиев А.М., Меджидова С.М. Азербайджанское нефтяное хозяйство. 6, $44(1996)$

60. Шахтахтинский Т.Н., Алиев А.М., Кулиев А.Р., Меджидова С.М.., Матиев К.И., Касум-заде А.Ю. Кинетика и катализ. 37, 286 (1996)

61.Матиев К.И., Касум-заде А.Ю., Меджидова С.М., Бабаева А.Р., Кулиев А.Р., Алиев A.M., Шахтахтинский Т.Н. Тезисы докл. Международной научно-технической конф. "Интенсификация процессов химической и пищевой технологии". "Процессы-93". Ташкент. 1993. Ч. I. С. 82

62. Алиев А.М., Матиев К.И., Касум-заде А.Ю. //Азербайджанский химический журнал 2, 12 (2011)

63. Алиев А.М., Касумзаде А.Ю., Меджидов Н.Д., Зайцева 3.А. //Азербайджанский химический журнал. 3, 16 (2010)

64. Алиев А.М., Меджидова С.М., Касум-заде А.Ю. //Азербайджанский химический журнал. 1, 16 (2010)

65. Алиев А.М., Алиханова 3.А., Сарыджанов А.А., Касумзаде А.Ю. //Доклады АН Азербайджана. 4, 46 (2010)

66. Алиев А.М., Алиханова 3.А., Сарыджанов А.А. //Азербайджанский химический журнал 3, 10, (2011)

67. Алиев А.М., Алиханова 3.А., Сарыджанов А.А., Кулиев А.Р., Меджидова С.М. Химические проблемы. 4, 696 (2008)

68. Алиев А.М., Алиханова 3.А., Сарыджанов А.А., Кулиев А.Р., Меджидова С.М. Азербайджанский химический журнал. 4, 16 (2008)

69. Шахтахтинский Т.Н., Алиев А.М., Алиханова 3.А., Сарыджанов А.А. Тезисы докладов I Международной конференции PXO им. Д.И.Менделеева "Ресурсо и энергосберегающие технологии в химической и нефтехимической промышленности" Москва 2009, с.79-80.

70. Алиев А.М., Меджидова С.М., Фатуллаева С.С., Ализаде Г.А. Тезисы докладов 6-й Всероссийской цеолитной конференции с международным участием "Цеолиты и мезопористые материалы, достижения и перспективы", посвященная 100-летию проф. К.В.Топчиевой. Звенигород. 2011. С.183

71. Santacesaria E., Gelosa D., George E. S. Journal of Catalysis 90, 1 (1984)

72. Santasesaria E., Gelosa D., Carra S. Journal of Catalysis, 80, 427 (1983)

73. Kurina L.N., Davydov A.A., Osipova N.A. In proceedings of the 5 th Intern. Symp. Relationns between homogenous and heterogenous catalysis. Novosibirsk, 1986. P.140.

74. Aliyev A.M., Mikailov R.Z., Shakhtakhtinsky T.N., Poladly P.F., Sarijanov A.A. Abstracts of the 1st Aegean physical chemistry days. 2002. Bornova-Izmir. Türkiye. P. 48.

75. Aliyev A.M., Sarijanov A.A., Kuliyev A.R., Tunc Savasci, Mikailov R.Z., Shakhtakhtinsky T.N., Sarioglan A., Poladly P.F., Kuliyev A.R. In proceedings of the 2nd International FEZA (Federation of the Europen Zeolite Assosiations) conference. Taormina, Italy. 2002. PART A. P. 787-794. 
76. Матиев К.И. Газофазное окисление изопропилового и изоамилового спиртов на металлцеолитных катализаторах. Дис. канд. хим. наук. ИТПХТ АН Азерб., Баку. 1998.

77. Алиханова 3.А., Алиев А.М., Сарыджанов А.А., Бахманов М.Ф. Изв. Вузов "Химия и химическая технология" г. Иваново, 11, 106 (2009)

78. Меджидова С.М. //Азербайджанский химический журнал 4, 138 (2010)

79. Алиев А.М., Ибрагимов 3.И., Магеррамов В.Р., Абдуллаев А.Р., Исмаилов О.А. Азербайджанский химический журнал. 4, 12 (2006)

8о. Алиев А.М., Бабаев А.И., Меджидов Н.Д., Касум-заде А.Ю., Абдуллаев А.Р. Азербайджанский химический журнал. 2, 60 (2006)

81. Алиев А.М., Касум-заде А.Ю., Кулиев А.Р., Меджидова С.М. Азербайджанский химический журнал. 2, 63 (2000)

82. Pines H., Csicery S.M.. J. Amer. Chem. Soc. 84, 292 (1962)

83. Ягодовский В.Д., Псху З.В., Исаева Н.Ю., Ягодовская Т.В., Кифяк Р.А., Беляева К.С. //Журнал физической химии. 83, 847 (2009) 39 (1998)

84. Koel Bruce E., Blank David A., Carter Emily A. //Journal of Molecular Catalysis A. 131,

85. Biniwale Rajesh B., Kariya N., Ichikawa M. //Catalysis Letters. 105, 83 (2005)

86. Тагиев Д.Б., Миначев Х.М. //Успехи химии. 50, 1935 (1981)

87. Алиев А.М., Шабанова З.А., Наджаф-Кулиев У.М., Меджидова С.М., Али-заде Г.А. // Химическая промышленность, Москва. 3, 109 (2014)

88. Lunsford I.H. Langmuir. 5, 12 (1989)

89. Синев М.Ю., Коршак В.Н., Крылов О.В. //Успехи химии. 58, 38 (1989)

90. Amenomiya J., Birss V., Goledrinovski M. //Catalysis Rev. 32, 163 (1990)

91.Lunsford I.H. //Catalysis Today. 6, 235 (1990)

92. Duboix I.L., Cameron L.D. //Appl. Catalysis. 67, 49 (1990)

93. Mackie J.C. //Catalysis Rev. 33, 169 (1991)

94. Labinger I.A., Ott K.C. //J. Phys. Chem. 91, 2682 (1987)

95. McCarry I.G. In Proceedings of the 1 st World Congress. New Developments in Selective Oxidation (Rimini, Italy, 1989): Amsterdam: Elsevier. 1990. P. 393.

96. Chen H. //Chinese J. Natural Gas Chem. 4, 13 (1990)

97. Алиев А.М., Азизов А.О., Микаилов Р.З. Материалы Конф. стран Содружества по кинетике гетерогенно-каталитических реакций. Кинетика-5. Иваново. 1992. С.13.

98. Миначев Х.М., Усачев Н.Я., Удут В.Н., Ходаков Ю.С., Макаров П.А. //Изв. АН СССР. Сер. хим. 9, 2124 (1987)

99. Otsuka K., Lin Q., Morikawa A. //J. Chem. Soc., Chem. Commun 8, 586 (1986)

100. Otsuka K, Haiano M., Lin Q., Morikawa A. In proceedings of the 8 th Japan USSR Catalytical Seminar.Catalysis by New Materials. Tokyo, 1986. P. 1.

101. Пат. ФРГ 3503664 (1986)

102.Алиев А.М., Алиев Ф.В., Матиев К.И., Мамедова У.А. Материалы Научной Конференции посвященная 105 летнему юбилею академика М.Ф.Нагиева., Баку, 2013. С. 19.

103.Кирпичников П.А., Лиакумович А.Г., Победимский Д.Г. // Химия и технология мономеров для синтетических каучуков. Учебное пособие для вузов. Химия 1981. 263 с.

\section{References:}

1. Minachev H.M., Isakov Ja.I. Metallsoderzhashhie ceolity v katalize, M.: «Nauka», 1976. $111 \mathrm{~s}$.

2. Landau M.V., Kruglikov V.Ja., Konoval'chikov O.D. //Himija i tehnologija topliv i masel. 4, 10 (1976)

3. Patent US 4237073 (1980)

4. Zhdanov S.P., Hvoshhev S.S., Samulevich N.N. Sinteticheskie ceolity, M.: «Himija», 1981. $264 \mathrm{~s}$.

5. $\quad$ Kasamanski V.P. Dis. kand. him. nauk. INFH AN Azerb. SSR, Baku, 1982

6. Kasum-zade A.Ju. Dis. kand. him. nauk. ITPHT AN Azerb. SSR, Baku, 1992

7. Muradov M.H. Dis. kand. him. nauk. ITPHT im. M.F.Nagieva AN Azerbajdzhana, Baku, 1999. 
8. Gusejnov K.A. Dis. kand. him. nauk. IHP im. M.F.Nagieva Nacional'noj AN Azerbajdzhana, Baku, 2009.

9. Fatullaeva S.S. Dis. kand. him. nauk. IHP im. M.F.Nagieva Nacional'noj AN Azerbajdzhana, Baku, 2004.

10. Aliev A.M., Shabanova Z.A., Nadzhaf-Kuliev U.M., Medzhidova S.M., Ali-zade G.A. //Neftepererabotka i neftehimija. 5, 27 (2013)

11. Azizov A.O. Dis. kand. him. nauk. ITPHT AN Azerb. SSR, Baku, 1991, 124 s.

12. Aliyev A.M., Aliyev F.V., Matiyev K.I., M. Al-Dosari. In the proceedings of the 15th International Congress on Catalysis. Munich, Germany, 2012. Vol.1. P.1508

13. Shahtahtinskij T.N., Aliev A.M., Kuliev A.R., Bjenni Harri F., Kasamanskij V.P., Peresada I.M. //Azerbajdzhanskij himicheskij zhurnal. 2, 41 (1979)

14. Aliev A.M., Kuliev A.R., Kasamanskij V.P., Mikailov R.Z. HII Mendeleevskij s\#ezd po obshhej i prikladnoj himii. Referaty dokladov i soobshhenij. M.: Nauka, 1981. S. 75.

15. Shakhtakhtinsky T.N., Aliyev A.M., Kuliyev A.R., Kasamansky V.P. In the proceedings of the 6 th American-Soviet Symposium on Chemical Catalysts. USA. New Jersey, Cherry Hill. June, 1979. P. 143.

16. Aliev A.M., Kasamanskij V.P., Shahtahtinskij T.N., Kuliev A.R., Mikailov R.Z., Ismajlov Je.G. Tezisy dokladov II Vsesojuznoj konf. po primeneniju ceolitov v katalize. Moskva. 1981. S. 199. 17. Shahtahtinskij T.N., Aliev A.M., Kuliev A.R., Bjenni Harri F., Kasa $\neg$ man $\neg$ skij V.P., Mikailov R.Z. Azerbajdzhanskij himicheskij zhurnal. 2, 57 (1979).

18. Aliyev A.M., Mikailov R.Z., Azizov A.O., Yariyev V.M., Yu $\neg$ nisova F.A., Efendiev A.A. In the Proceedings of Symp. Industrial Applications of Zeolites. Brugge, Belgium. 2000. P. 251.

19. Aliev A.M., Mikailov R.Z., Gasanov Je.A., Agaeva R.Ju. Azerbajdzhanskij hi $\neg$ mi-cheskij zhurnal. 1, 10 (2004)

20. Shahtahtinskij T.N., Aliev A.M., Kuliev A.R., Kasamanskij V.P., Mikailov R.Z.. Tezisy dokladov V Mezhdunarodnogo simpoziuma po geterogennomu katalizu. Varna. 1983. T. 1. S.147.

21. Aliev A.M., Abdullaev R.H., Mamedov A.A., Mikailov R.Z., Agaeva R.Ju. Azerbajdzhanskij himicheskij zhurnal. 2, 7 (2000)

22. A.M.Aliev, R.Z. Mikailov, Je.A. Gasanov, R.Ju. Agaeva. Azerbajdzhanskij himicheskij zhurnal. 3, 118 (2006).

23. Shahtahtinskij T.N., Aliev A.M., Kuliev A.R., Kasamanskij V.P., Mikailov R.Z. Z.I. Ibragimov. Kinetika i kataliz. T. 27. 4, 966 (1986)

24. Mikailov R.Z. Dis.kand. him. nauk. ITPHT AN Azerb. SSR, Baku. 1984.

25. Brajlovskij S.M., Temkin O.N., Trofimova I.V. Problemy kinetiki i kataliza. M.: Nauka, 1985. T. 19. S. 146.

26. Nishmure Psutomu // J. Catal. 48, 413 (1977)

27. Jakovenko Z.I., Kolganova S.A., Kurina M.N. Zhurnal fizicheskoj himii. 59, 253 (1986) (1998)

28. Klissurski Dimiter G., Abadzhjieva Nevena T., Triffiro F. Bulg. Chem. Commun. 30, 448

29. Keleypette Dono, Zhu Zhi-hua, Xu Pei-Zuo // J E China Univ., Sci. and Technol. 26, 134 (2000)

30. Mao C.F., Vannice M.A. // J. Catal. 154, 230 (1995)

31. Naoki Narishige, Miki Niwa // Catalysis Letter. 71, 63 (2001) (1990)

32. Lazareva T.V., Osipova N.A., Kurina L.N. Izv. VUZov. Himija i him. Tehnologija. 33, 49

33. Mahipal Reddy B., Narsimha R., Sivaraj Ch., Kanta Rao P. Appl. Catal. 55, 41 (1989)

34. Wong G.S., Kragten D.D., Vohs J.M. // J. Phys. Chem. B. 105, 1366 (2001)

35. Soares A.P.V., Portela Farinha, A. Kiennemann, L.Hilaire, J.M.Millet. Applied Catalysis. A: General. 206, 221 (2001)

36. Koltunov K. Yu., Sobolev V. I. Catalysis in Industry., 4, 247 (2012)

37. Kurina L.N., Osipova N.A., Davydov A.A. // Dep. VINITI. №5082-V87 (Moskva, 1987).

38. Patent SU № 1817768 AZ (Gospatent SSSR) (1993)

39. Patent i 20030204 Az.R. (2003)

40. A.s. № 1549945 SSSR. Zaregistrirovano v Gos. reestre izobretenij SSSR 15 nojabrja 1989 g. // Opublikovano 15.03.90. 
41. Aliev A.M. Tezisy dokladov III Mezhdunarodnoj konf. "Tonkij organicheskij sintez i kataliz", posvjashhennaja 85-letnemu jubileju AGNA. Baku. 2005. S. 25

42. Aliev A.M., Kuliev A.R., Gusejnov K.A., Medzhidova S.M., Alizade G.A., Agaeva R.Ju. //Azerbajdzhanskij himicheskij zhurnal. 2, 121 (2006) g. DSP.

43. A.s. № 1372874 SSSR. Zaregistrirovano v Gos. reestre izobretenij SSSR 8 oktjabrja 1987

44. Aliyev A.M., Shakhtakhtinsky T.N., Ali A.Ghorbanpour, Alikhanova Z.A., Guseynov K.A., Agayeva R..Yu., Sarijanov A.A., Matiyev K.I. In the proceedings of the 6th World Congress on Oxidation Catalysis. Towards an Integrated Approarch in Innovation and Development. Lille, France. 2009. Poster Session A. 1B-92. P. 110

45. Aliev A.M., Medzhidova S.M., Shahtahtinskij T.N., Gusejnov K.A. Izv. Vuzov Himija i himicheskaja tehnologija. 53, 95 (2010)

46. Aliev A.M., Medzhidova S.M., Gusejnov K.A., Alizade G.A., Agaeva R.Ju., Kasum-zade A.Ju., Mamedova U.A. Trudy HIH Mendeleevskogo s\#ezda po obshhej i prikladnoj himii. Volgograd, Rossija. 2011. S.466.

47. Gusejnov K.A. Him. Problemy, 3, 582 (2007)

48. Aliev A.M., Kesamanskaja S.V., Babaeva A.R., Seidov A.G., Kuliev A.R. IV Vsesojuznaja konf. "Primenenie ceolitov v katalize". Moskva, 1989. S. 189.

49. Shahtahtinskij T.N., Aliev A.M., Kuliev A.R., Medzhidova S.M., Muradov M.H. Dokl. AN Rossii. 343, 496(1995)

50. Medzhidova S.M. Him. problemy. 4, 695 (2010)

51. Aliyev A.M., Medjidova S.M, Kuliyev A.R., Shakhtakhtinsky T.N., Fatullayeva S.S., Tagiev D.B., Sarijanov A.A., Agayeva R.Y. Abstracts of the 1st Aegean Physical Chemistry days. 2002. Bornova-Izmir. Türkiye. P.307

52. Aliyev A.M., Tagiev D.B., Fatullaeva S.S., Kuliev A.R., Mejidova S.M. Abstracts of the 17 th International conf. of Chemical Reactors "Chemreactor-17". 2006. Athens-Crete, Greece. PP. 121. P. 701-704.

53. Aliyev A.M., Medzhidova S.M., Shakhtakhtinski T.N., Kuliev A.R., Agayeva R.Yu, Kasumzade A.Yu., Fatullaeva S.S. In the Proceedings of Symp. Industrial Applications of Zeolites. Brugge, Belgium, 2000. P. 245.

54. A.M.Aliyev, D.B.Tagiev, S.M.Medzhidova, S.S Fatullaeva., A.R Kuliyev., T.N. Shakhtakhtinsky, G.A.Alizade, K.I. Matiyev. In the Proceedings of the 13th International Zeolite Conf. Zeolites and Mezoporous Materials of the Down of the 21st Sentury”. 2001. Fran $\neg$ ce, Montpellier. 27-P-08. R. 365.

55. S.M.Medzhidova. Azerbajdzhanskij himicheskij zhurnal. 4, 138 (2010)

56. A.M. Aliyev, D.B.Tagiev, S.M.Mejidova, A.R.Kuliyev, S.S.Fatullayeva, G.Alizade, R.Y.Agayeva. Abstracts of the 39 th TOPAC International Congress and 86 Conference of the Zeo $\neg$ lite. Canadian Society for Chemistry. 2003. Ottawa-Ontario-Canada. IN-5 Poster (1998)

57. K.I.Matiev, A.M.Aliev, S.M.Medzhidova. Azerbajdzhanskoe neftjanoe hozjajstvo. 1, 40

58. Aliev A.M., Kuliev A.R., Medzhidova S.M., Matiev K.I., Kasum-zade A.Ju. Tezisy dokladov II Bakinskoj Mezhdunarodnoj neftjanoj konf., posvjashhennaja pamjati akad. Ju.G.Mamedalieva. Baku. 1996. S. 164. (1996)

59. Matiev K.I., Aliev A.M., Medzhidova S.M. Azerbajdzhanskoe neftjanoe hozjajstvo. 6, 44

6o. Shahtahtinskij T.N., Aliev A.M., Kuliev A.R., Medzhidova S.M.., Matiev K.I., Kasum-zade A.Ju. Kinetika i kataliz. 37, 286 (1996)

61. Matiev K.I., Kasum-zade A.Ju., Medzhidova S.M., Babaeva A.R., Kuliev A.R., Aliev A.M., Shahtahtinskij T.N. Tezisy dokl. Mezhdunarodnoj nauchno-tehnicheskoj konf. "Intensifi $\neg$ kacija processov himicheskoj i pishhevoj tehnologii". "Processy-93". Tashkent. 1993. Ch. I. S. 82 (2011)

62. Aliev A.M., Matiev K.I., Kasum-zade A.Ju. //Azerbajdzhanskij himicheskij zhurnal 2, 12

63. Aliev A.M., Kasumzade A.Ju., Medzhidov N.D., Zajceva Z.A. //Azerbajdzhanskij himicheskij zhurnal. 3, 16 (2010)

64. Aliev A.M., Medzhidova S.M., Kasum-zade A.Ju. //Azerbajdzhanskij himicheskij zhurnal. 1, 16 (2010) 
65. Aliev A.M., Alihanova Z.A., Sarydzhanov A.A., Kasumzade A.Ju. //Doklady AN Azerbajdzhana. 4, 46 (2010) $10,(2011)$

66. Aliev A.M., Alihanova Z.A., Sarydzhanov A.A. //Azerbajdzhanskij himicheskij zhurnal 3,

67. Aliev A.M., Alihanova Z.A., Sarydzhanov A.A., Kuliev A.R., Medzhidova S.M. Himicheskie problemy. 4, 696 (2008)

68. Aliev A.M., Alihanova Z.A., Sarydzhanov A.A., Kuliev A.R., Medzhidova S.M. Azerbajdzhanskij himicheskij zhurnal. 4, 16 (2008)

69. Shahtahtinskij T.N., Aliev A.M., Alihanova Z.A., Sarydzhanov A.A. Tezisy dokladov I Mezhdunarodnoj konferencii RHO im. D.I.Mendeleeva "Resurso i jenergosberegajushhie tehnologii v himicheskoj i neftehimicheskoj promyshlennosti" Moskva 2009, s.79-80.

70. Aliev A.M., Medzhidova S.M., Fatullaeva S.S., Alizade G.A. Tezisy dokladov 6-j Vserossijskoj ceolitnoj konferencii $\mathrm{s}$ mezhdunarodnym uchastiem "Ceolity i mezoporistye materialy, dostizhenija i perspektivy", posvjashhennaja 100-letiju prof. K.V.Topchievoj. Zvenigorod. 2011. S.183

71. Santacesaria E., Gelosa D., George E. S. Journal of Catalysis 90, 1 (1984)

72. Santasesaria E., Gelosa D., Carra S. Journal of Catalysis, 80, 427 (1983)

73. Kurina L.N., Davydov A.A., Osipova N.A. In proceedings of the 5 th Intern. Symp. Relationns between homogenous and heterogenous catalysis. Novosibirsk, 1986. P.140.

74. Aliyev A.M., Mikailov R.Z., Shakhtakhtinsky T.N., Poladly P.F., Sarijanov A.A. Abstracts of the 1st Aegean physical chemistry days. 2002. Bornova-Izmir. Türkiye. P. 48.

75. Aliyev A.M., Sarijanov A.A., Kuliyev A.R., Tunc Savasci, Mikailov R.Z., Shakhtakhtinsky T.N., Sarioglan A., Poladly P.F., Kuliyev A.R. In proceedings of the 2nd In-ternational FEZA (Federation of the Europen Zeolite Asso $\neg$ siations) conference. Taormina, Italy. 2002. PART A. P. 787-794.

76. Matiev K.I. Gazofaznoe okislenie izopropilovogo i izoamilovogo spirtov na metallceolitnyh katalizatorah. Dis. kand. him. nauk. ITPHT AN Azerb., Baku. 1998.

77. Alihanova Z.A., Aliev A.M., Sarydzhanov A.A., Bahmanov M.F. Izv. Vuzov "Himija i himicheskaja tehnologija" g. Ivanovo, 11, 106 (2009)

78. Medzhidova S.M. //Azerbajdzhanskij himicheskij zhurnal 4, 138 (2010)

79. Aliev A.M., Ibragimov Z.I., Magerramov V.R., Abdullaev A.R., Ismailov O.A. Azerbajdzhanskij himicheskij zhurnal. 4, 12 (2006)

80. Aliev A.M., Babaev A.I., Medzhidov N.D., Kasum-zade A.Ju., Abdullaev A.R. Azerbajdzhanskij himicheskij zhurnal. 2, 60 (2006)

81. Aliev A.M., Kasum-zade A.Ju., Kuliev A.R., Medzhidova C.M. Azer $\neg$ bajdzhanskij himicheskij zhurnal. 2, 63 (2000)

82. Pines H., Csicery S.M.. J. Amer. Chem. Soc. 84, 292 (1962)

83. Jagodovskij V.D., Pshu Z.V., Isaeva N.Ju., Jagodovskaja T.V., Kifjak R.A., Beljaeva K.S. //Zhurnal fizicheskoj himii. 83, 847 (2009)

84. Koel Bruce E., Blank David A., Carter Emily A. //Journal of Molecular Catalysis A. 131, 39 (1998)

85. Biniwale Rajesh B., Kariya N., Ichikawa M. //Catalysis Letters. 105, 83 (2005)

86. Tagiev D.B., Minachev H.M. //Uspehi himii. 50, 1935 (1981)

87. Aliev A.M., Shabanova Z.A., Nadzhaf-Kuliev U.M., Medzhidova S.M., Ali-zade G.A. //Himicheskaja promyshlennost', Moskva. 3, 109 (2014)

88. Lunsford I.H. Langmuir. 5, 12 (1989)

89. Sinev M.Ju., Korshak V.N., Krylov O.V. //Uspehi himii. 58, 38 (1989)

90. Amenomiya J., Birss V., Goledrinovski M. //Catalysis Rev. 32, 163 (1990)

91. Lunsford I.H. //Catalysis Today. 6, 235 (1990)

92. Duboix I.L., Cameron L.D. //Appl. Catalysis. 67, 49 (1990)

93. Mackie J.C. //Catalysis Rev. 33, 169 (1991)

94. Labinger I.A., Ott K.C. //J. Phys. Chem. 91, 2682 (1987)

95. McCarry I.G. In Proceedings of the 1 st World Congress. New Developments in Selective

Oxidation (Rimini, Italy, 1989): Amsterdam: Elsevier. 1990. P. 393.

96. Chen H. //Chinese J. Natural Gas Chem. 4, 13 (1990) 
97. Aliev A.M., Azizov A.O., Mikailov R.Z. Materialy Konf. stran Sodruzhes $\neg$ tva po kinetike geterogenno-kataliticheskih reakcij. Kinetika-5. Ivanovo. 1992. S.13.

98. Minachev X.M., Usachev H.Ja., Udut V.N., Hodakov Ju.S., Makarov P.A. //Izv. AN SSSR. Ser. him. 9, 2124 (1987)

99. Otsuka K., Lin Q., Morikawa A. //J. Chem. Soc., Chem. Commun 8, 586 (1986)

100. Otsuka K, Haiano M., Lin Q., Morikawa A. In proceedings of the 8 th Japan USSR Catalytical Seminar.Catalysis by New Materials. Tokyo, 1986. P. 1.

101. Pat. FRG 3503664 (1986)

102. Aliev A.M., Aliev F.V., Matiev K.I., Mamedova U.A. Materialy Nauchnoj Konferencii posvjashhennaja 105 letnemu jubileju akademika M.F.Nagieva., Baku, 2013. S. 19.

103. Kirpichnikov P.A., Liakumovich A.G., Pobedimskij D.G. // Himija i tehnologija monomerov dlja sinteticheskih kauchukov. Uchebnoe posobie dlja vuzov. Himija 1981. $263 \mathrm{~s}$.

УДК 541311

\title{
Цеолиты модифицированные катионами металлов как катализаторы в реакциях окисления углеводородов и алифатических спиртов
}

\author{
${ }^{1}$ Агададаш Махмуд огды Алиев \\ 2 Зумруд Абдулмуталлиб кызы Шабанова \\ з Фикрет Вахид Алиев \\ 4 Алла Михаловна Гусейнова
}

1-4 Институт Катализа и неорганической химии им. М.Ф.Нагиева, НАНА, Азербайджан

Az1143, г.Баку-143, пр. Г. Джавида, 113

${ }^{1}$ Академик, доктор химических наук

E-mail: iradam@rambler.ru

2 Доктор философии по химии, ведущий научный сотрудник

E-mail:iradam@rambler.ru

3 Научный сотрудник

E-mail: iradam@rambler.ru

${ }_{4}^{4}$ Кандидат химических наук, ведущий научный сотрудник

E-mail: iradam@rambler.ru

Аннотация. Представлены результаты исследований по созданию высокодисперсных металлцеолитных систем и изучение их каталитического действия в реакциях окисления низших олефиновых углеводородов (этилена в ацетальдегид, пропилена в ацетон, бутиленов в метилэтилкетон); алифатических спиртов $\mathrm{C}_{1}-\mathrm{C}_{5}$ в соответствующие им альдегиды, кетоны, карбоновые кислоты и сложные эфиры карбоновых кислот; окислительного дегидрирования нафтенов в алициклические диеновые углеводороды и окислительной димеризации метана в ацетилен. Установлено, что селективность действия этих катализаторов определяется оптимальным сочетанием в них металлического компонента с кислотностью и структурой цеолита. Подобраны высокоэффективные катализаторы для исследуемых реакций. На основе результатов экспериментальных исследований кинетических закономерностей протекания реакций окисления низших олефиновых углеводородов и алифатических спиртов, окислительного дегидрирования нафтенов и окислительной димеризации метана на синтезированных катализаторах представлены их вероятные стадийные механизмы и разработаны кинетические модели реакций.

Ключевые слова: металлеолитные катализаторы; окисление; углеводороды; алифатические спирты. 